\title{
Antiplatelet and antithrombotic effects of cordycepin-enriched WIB-801CE from Cordyceps militaris ex vivo, in vivo, and in vitro
}

Hyuk-Woo Kwon ${ }^{1 \dagger}$, Jung-Hae Shin ${ }^{1 \dagger}$, Deok Hwi Lim" ${ }^{1 \dagger}$, Woo Jeong Ok', Gi Suk Nam, Min Ji Kim¹, Ho-Kyun Kwon², Jun-Hee Noh², Je-Young Lee ${ }^{2}$, Hyun-Hong Kim', Jong-Lae Kim ${ }^{2^{*}}$ and Hwa-Jin Park*

\begin{abstract}
Background: A species of the fungal genus Cordyceps has been used as a complementary and alternative medicine of traditional Chinese medicine, and its major component cordycepin and cordycepin-enriched WIB-801CE are known to have antiplatelet effects in vitro. However, it is unknown whether they have also endogenous antiplatelet and antithrombotic effects. In this study, to resolve these doubts, we prepared cordycepin-enriched WIB-801CE, an ethanol extract from Cordyceps militaris-hypha, then evaluated its ex vivo, in vivo, and in vitro antiplatelet and antithrombotic effects.

Methods: Ex vivo effects of WIB-801CE on collagen- and ADP-induced platelet aggregation, serotonin release, thromboxane $A_{2}\left(T_{X A_{2}}\right)$ production and its associated activities of enzymes [cyclooxygenase-1 (COX-1), TXA 2 synthase (TXAS)], arachidonic acid (AA) release and its associated phosphorylation of phospholipase $C_{\beta 3}$,

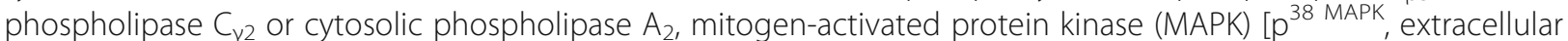
signal-regulated kinase (ERK)], and blood coagulation time in rats were investigated. In vivo effects of WIB-801CE on collagen plus epinephrine-induced acute pulmonary thromboembolism, and tail bleeding time in mice were also inquired. In vitro effects of WIB-801CE on cytotoxicity, and fibrin clot retraction in human platelets, and nitric oxide (NO) production in RAW264.7 cells or free radical scavenging activity were studied.

Results: Cordycepin-enriched WIB-801CE inhibited ex vivo platelet aggregation, TXA 2 production, AA release, TXAS activity, serotonin release, and $\mathrm{p}^{38 \mathrm{MAPK}}$ and ERK2 phosphorylation in collagen- and ADP-activated rat platelets without affecting blood coagulation. Furthermore, WIB-801CE manifested in vivo inhibitory effect on collagen plus epinephrine-induced pulmonary thromboembolism mice model. WIB-801CE inhibited in vitro NO production and fibrin clot retraction, but elevated free radical scavenging activity without affecting cytotoxicity against human platelets.

(Continued on next page)
\end{abstract}

\footnotetext{
* Correspondence: kimjl@whanin.com; mlsjpark@inje.ac.kr

${ }^{\dagger}$ Equal contributors

${ }^{2}$ Central Research Center, Whanin Pharm. Co., Ltd., 107, Gwanggyo-ro,

Suwon, Gyeonggi-do 16229, Korea

${ }^{1}$ Department of Biomedical Laboratory Science, College of Biomedical

Science and Engineering, Inje University, 197, Inje-ro, Gyungnam, Gimhae

50834, Korea
} 
(Continued from previous page)

Conclusion: WIB-801CE inhibited collagen- and ADP-induced platelet activation and its associated thrombus formation ex vivo and in vivo. These were resulted from down-regulation of TXA $\mathrm{T}_{2}$ production and its related AA release and TXAS activity, and $\mathrm{p}^{38}$ MAPK and ERK2 activation. These results suggest that WIB-801CE has therapeutic potential to treat platelet activation-mediated thrombotic diseases in vivo.

Keywords: WIB-801CE, Cordycepin, Platelet aggregation, TXA 2 , Serotonin, Thromboxane $\mathrm{A}_{2}$ synthase, Arachidonic acid release, $\mathrm{p}^{38 \text { MAPK }}$, ERK2, Thrombus

\section{Background}

A species of the fungal genus Cordyceps is known to prescribe for inflammatory and cancer disease $[1,2]$. It is reported that cordycepin (3'-deoxyadenosine, Fig. 1a), a major component of Cordyceps militaris, has in vitro antithrombotic effects by attenuating $\left[\mathrm{Ca}^{2+}\right]_{\mathrm{i}}$ level and thromboxane $\mathrm{A}_{2}\left(\mathrm{TXA}_{2}\right)$ production in collagen-induced human platelet aggregation [3]. However, there is no evidence or report concerning ex vivo and in vivo inhibitory effect of cordycepin or cordycepin-enriched substance on platelet activation.

In this study, to resolve this doubtful point, we prepared cordycepin-enriched WIB-801CE (Compound from 2008 First Project of Bioteam, Whanin Pharm. Co., Ltd., Suwon, Korea), an ethanol extract from Cordyceps militaris-hypha. Next, to observe whether WIB-801CE has endogenous inhibitory effects on platelet activation associated with thrombus formation, we orally administered WIB-801CE to rat, and subsequently investigated the effects on major molecules associated with $\mathrm{Ca}^{2+}$ increase [4-7], arachidonic acid (AA) release $[4,6,8-10], \mathrm{TXA}_{2}$ production $[4,5,8,11-13]$ and serotonin release [13-16].

\section{Methods}

\section{Materials}

WIB-801CE was provided from Whanin Pharmaceutical Corporation (Suwon, Korea). Collagen, adenosine diphosphate (ADP) and thrombin were obtained from Chrono-Log Corporation (Havertown, PA, USA). Serotonin enzyme-linked immunosorbent assay (ELISA) kit was purchased from Labor Diagnostika Nord GmbH \& Corporation (Nordhorn, Germany). Pure cordycepin, aspirin, protease inhibitor cocktail, 2,2-diphenyl-1picrylhydrazyl (DPPH), ascorbic acid (AC), and other reagents were obtained from Sigma Chemical Corporation (St. Louis, MO, USA). Thromboxane $\mathrm{B}_{2}\left(\mathrm{TXB}_{2}\right)$ enzyme immunoassay (EIA) kit, cyclooxygenase-1 (COX-1) fluorescent activity assay kit, lactate dehydrogenase (LDH) cytotoxicity assay kit, ozagrel and prostaglandin $\mathrm{H}_{2}\left(\mathrm{PGH}_{2}\right)$ for $\mathrm{TXA}_{2}$ synthase (TXAS) assay were purchased from Cayman Chemical (Ann Arbor, MI, USA). Arachidonic acid (AA) release ELISA kit was purchased from Cusabio Biotech Corporation (Wuhan, Hubei, China). Antiphosphor-cytosolic phospholipase $\mathrm{A}_{2}\left(\mathrm{cPLA}_{2}\right)\left(\mathrm{Ser}^{505}\right)$, anti-phosphor-phospholipase $\mathrm{C}_{\beta 3} \quad\left(\mathrm{PLC}_{\beta 3}\right) \quad\left(\mathrm{Ser}^{537}\right)$, anti-phosphor-phospholipase $\mathrm{C}_{\beta 3} \quad\left(\mathrm{PLC}_{\beta 3}\right)\left(\mathrm{Ser}^{1105}\right)$, anti-phosphor-phospholipase $\mathrm{C}_{\gamma_{2}} \quad\left(\mathrm{PLC}_{\gamma_{2}}\right) \quad\left(\mathrm{Tyr}^{1217}\right)$, anti-phosphor-p $^{38}$ MAPK, anti-phosphor-extracellular signal-regulated kinase (ERK) (1/2), anti-p ${ }^{38}$ MAPK , anti-ERK $(1 / 2)$ and anti-rabbit immunoglobulin G (IgG)-horseradish peroxidase conjugate (HRP), and lysis buffer were obtained from Cell Signaling (Beverly, MA, USA). Polyvinylidene difluoride (PVDF) membrane was from General Electric Healthcare (Piseataway, NJ, USA). Enhanced chemiluminescence solution (ECL) was from General Electric Healthcare (Chalfont St. Giles, Buckinghamshire, UK). Prothrombin time (PT) assay reagent and activated partial thromboplastin time (APTT) assay reagent were obtained from Fisher Diagnostics (Middletown, VA, USA).

\section{Preparation of WIB-801CE}

Cordyceps militaris was cultivated, and culture-solution of Cordyceps militaris-hypha was concentrated up to $50^{\circ}$ Brix with a rotary vacuum evaporator (Eyela N3000, Rikakikai Co., Ltd., Tokyo, Japan) at $60{ }^{\circ} \mathrm{C}$. The Brix was measured with refractometer (Atago Co., Ltd., Tokyo, Japan). The concentrate was extracted by extraction-shaker (Cosmos 660, Kyungseo Co., Ltd., Seoul, Korea) for $4 \mathrm{~h}$ at $40{ }^{\circ} \mathrm{C}$ one time with distilled water $/ 95 \%$ ethanol $(1: 3.5, \mathrm{v} / \mathrm{v})$, which was filtered one time using a filter paper (Advantec No.2). The filtrate was completely concentrated at $60^{\circ} \mathrm{C}$ by an evaporator (Eyela N3000, Rikakikai Co., Ltd., Tokyo, Japan) under reduced pressure, and was lyophilized and stored at $-20{ }^{\circ} \mathrm{C}$ until used. This was named as cordycepin-enriched WIB-801CE.

\section{Analysis of cordycepin in WIB-801CE with HPLC}

WIB-801CE was dissolved with 75\% methanol, then analyzed by high performance liquid chromatography (HPLC). An Alliance 2695 liquid chromatography system (Waters Co., Milford, MA, USA), equipped with vacuum degasser, quaternary gradient pump, autosampler and photodiode array detector, was connected to Empower software. A hydrosphere $\mathrm{C}_{18}$ column $(250 \mathrm{~mm} \times 4.6 \mathrm{~mm}$ id, $5 \mu \mathrm{m}$, YMC Co., Ltd., Kyoto, Japan) was used at a column temperature of $30^{\circ} \mathrm{C}$. The applied-mobile phase gradient program was $0.01 \mathrm{M} \mathrm{KH}_{2} \mathrm{PO}_{4} /$ methanol $(95: 5, \mathrm{v} / \mathrm{v})$ at 


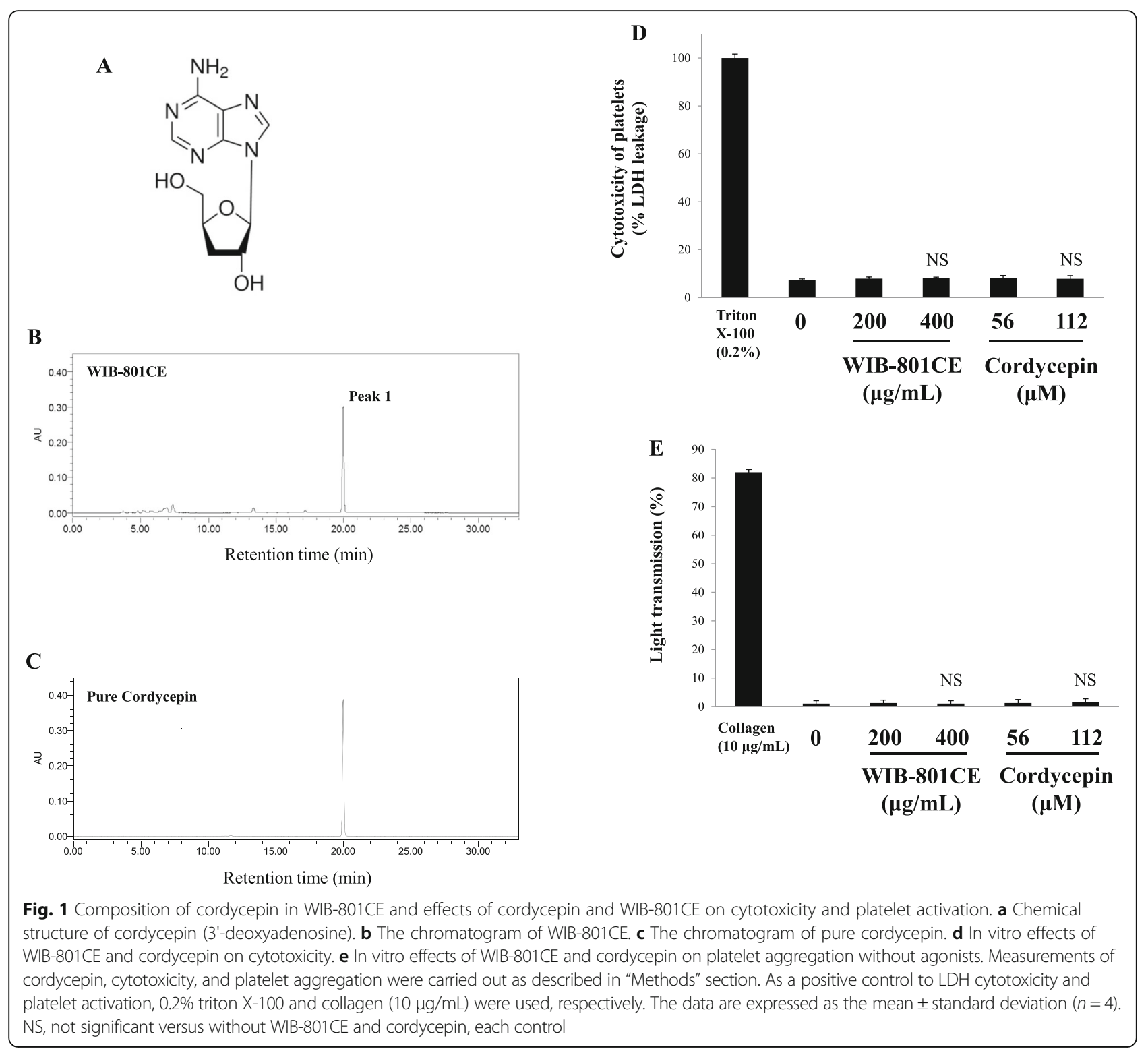

0 min and held for 5 min; $0.01 \mathrm{M} \mathrm{KH}_{2} \mathrm{PO}_{4} /$ methanol v/v) at $20 \mathrm{~min}$ and held for $6 \mathrm{~min} ; 0.01 \mathrm{M} \mathrm{KH}_{2} \mathrm{PO}_{4} /$ methanol $(95: 5, \mathrm{v} / \mathrm{v})$ at $27 \mathrm{~min}$ and held $6 \mathrm{~min}$ for chromatographic balance. In this step, $99.8 \%$ of methanol was used. The flow rate was at $1.0 \mathrm{~mL} / \mathrm{min}$ and sample injection volume was $10 \mu \mathrm{L}$. The ultra violet detection was operated at $254 \mathrm{~nm}$.

\section{Animals and administration}

We investigated the ex vivo and in vivo effects of WIB$801 \mathrm{CE}$ using rats (Sprague-Dawley, male, $200 \mathrm{~g}$ ) and Institute of Cancer Research (ICR) mice (male, $18 \mathrm{~g}$, Daehan Biolink Co., Ltd., Chungbook, Korea). Rats for ex vivo experiment and mice for in vivo observation were divided into as follows, respectively: WIB-801CE- nontreated group (control), WIB-801CE-treated group, aspirin-treated group as positive control of in vivo, and warfarin-treated group as positive control of ex vivo.

Animals were acclimatized for a week at a temperature of $24 \pm 1{ }^{\circ} \mathrm{C}$ and humidity of $55 \pm 5 \%$. Before oral administration of substances, all animals were fasted for $12 \mathrm{~h}$, then were fed with standard pellets diet (Purina Inc., Korea) had free access to water. WIB-801CE [200, $400 \mathrm{mg} / \mathrm{kg}$ body weight $(B W)]$ and warfarin $(1 \mathrm{mg} / \mathrm{kg}-\mathrm{BW})$ for ex vivo experiment were orally administered to the rats one per day for seven days, and WIB-801CE (200, $400 \mathrm{mg} / \mathrm{kg}-\mathrm{BW})$ and aspirin $(100 \mathrm{mg} / \mathrm{kg}-\mathrm{BW})$ for in vivo observation were orally administered to the mice once a day for five days. $200 \mathrm{mg} / \mathrm{kg}-\mathrm{BW}$ of WIB-801CE is corresponded to the minimum dose that inhibits rat platelet aggregation (data not shown). WIB-801CE, warfarin, and aspirin were 
dissolved with distilled water. The experiments were proved by the Ethics Committee for Animal Experiments of Whanin Pharmaceutical Corporation (Suwon, Korea/ 15-NE-016 for rats, 15-NE-008 for mice).

\section{Preparation of rat platelet-rich plasma and platelet-poor plasma for ex vivo assay}

After the final respective administration, all rats were fasted for $24 \mathrm{~h}$, then after $2 \mathrm{~h}$ of WIB-801CE- and warfarin-administration were anesthetized with $20 \%$ urethane before sacrifice according to the method of Zhang et al. [17]. The blood was collected from the abdominal aorta. The blood was anti-coagulated with acidcitrate-dextrose solution $(0.8 \%$ citric acid, $2.2 \%$ sodium citrate, $2.45 \%$ glucose), and was centrifuged at $250 \times \mathrm{g}$ for $10 \mathrm{~min}$ in order to obtain platelet-rich plasma (PRP). In order to remove residual red blood cells and white cells, the PRP was again centrifuged at $125 \times \mathrm{g}$ for $10 \mathrm{~min}$. Platelet-poor plasma (PPP) was prepared by centrifuging the part of PRP at $1,300 \times \mathrm{g}$ for $10 \mathrm{~min}$.

PRP was used to investigate ex vivo platelet aggregation, $\mathrm{TXA}_{2}$ production, serotonin release, COX-1 and TXAS activities, AA release and protein phosphorylation. PPP was used to investigate ex vivo PT and APTT. The number of platelets in PRP was adjusted with PPP to a final concentration of $5 \times 10^{8} / \mathrm{mL}$. All of the above procedures were carried out at $25{ }^{\circ} \mathrm{C}$ to avoid platelet aggregation from any effect of low temperature.

\section{Preparation of human PRP and washed platelets for in vitro assay}

To investigate in vitro effects of WIB-801CE and cordycepin on fibrin clot retraction, we used human PRP and washed platelets. PRP from normal healthy human volunteers with informed consent was obtained from the Korean Red Cross Blood Center (KRBC, Changwon, Korea), and its experimental use was approved by the KRBC (Safety Supervisor Team-621-2015.02.26) and the Korea National Institute for Bioethics Policy Public Institutional Review Board (Seoul, Korea/PIRB12-072-01) with informed consent. PRP anticoagulated with acidcitrate-dextrose solution $(0.8 \%$ citric acid, $2.2 \%$ sodium citrate, $2.45 \%$ glucose) was centrifuged for $10 \mathrm{~min}$ at $125 \times \mathrm{g}$ to remove a little red blood cells and white cells, which was used to investigate the effect of WIB-801CE and cordycepin on thrombin-induced fibrin clot retraction. The number of platelets in PRP was adjusted with PPP to a final concentration of $5 \times 10^{8} / \mathrm{mL}$.

To observe in vitro effects of WIB-801CE and cordycepin on cytotoxicity and resting platelet aggregation, we prepared human washed platelets. The PRP was centrifuged for $10 \mathrm{~min}$ at $1,300 \times \mathrm{g}$ to obtain platelet pellets. The platelets were washed twice with washing buffer (138 mM NaCl, $2.7 \mathrm{mM} \mathrm{KCl,} 12 \mathrm{mM} \mathrm{NaHCO}, 0.36 \mathrm{mM}$
$\mathrm{NaH}_{2} \mathrm{PO}_{4}, 5.5 \mathrm{mM}$ glucose, and $1 \mathrm{mM} \mathrm{Na} 2 \mathrm{EDTA}, \mathrm{pH}$ 6.5). The washed platelets were then resuspended in suspension buffer $(138 \mathrm{mM} \mathrm{NaCl}, 2.7 \mathrm{mM} \mathrm{KCl}, 12 \mathrm{mM} \mathrm{NaHCO}$, $0.36 \mathrm{mM} \mathrm{NaH} \mathrm{PO}_{4}, 0.49 \mathrm{mM} \mathrm{MgCl}_{2}, 5.5 \mathrm{mM}$ glucose, $0.25 \%$ gelatin, $\mathrm{pH} 6.9$ ) to a final concentration of $5 \times$ $10^{8} / \mathrm{mL}$. All of the above procedures were carried out at $25{ }^{\circ} \mathrm{C}$ to avoid platelet aggregation from any effect of low temperature. The Korea National Institute for Bioethics Policy Public Institutional Review Board (Seoul, Korea/PIRB12-072-01) approved these experiments.

\section{In vitro cytotoxicity assay}

Platelet cytotoxicity was determined by leakage of $\mathrm{LDH}$ from cytosol. Human washed platelets $\left(10^{8} / \mathrm{mL}\right)$ were incubated for $5 \mathrm{~min}$ at $37^{\circ} \mathrm{C}$ in the presence of WIB-801CE or cordycepin, then centrifuged with $12,000 \times \mathrm{g}$ at room temperature for $2 \mathrm{~min}$. The supernatant was measured with a synergy HT multi-model microplate reader (BioTek Instruments, Winooski, VT, USA) using LDH assay kit. $\mathrm{LDH}$ leakage was expressed as percentage of total $\mathrm{LDH}$ activity in platelets completely lysed by $0.2 \%$ triton X-100.

\section{Measurement of ex vivo rat platelet aggregation, and in vitro human resting platelet aggregation}

To evaluate antiplatelet effect of WIB-801CE under condition that generates maximally platelet aggregation, we used high dose of collagen and ADP as agonists. The concentration of collagen-induced maximal rat (SpragueDawley, male) platelet aggregation was $10 \mu \mathrm{g} / \mathrm{mL}$ [18], and $5 \mu \mathrm{M}$ of ADP was used to aggregate rat platelets [19]. Accordingly, we used $10 \mu \mathrm{g} / \mathrm{mL}$ of collagen, and $5 \mu \mathrm{M}$ of ADP to cause ex vivo rat platelet aggregation.

To measure ex vivo rat platelet aggregation, PRP $\left(10^{8}\right.$ platelets $/ \mathrm{mL}$ ) were preincubated with or without WIB$801 \mathrm{CE}$ for $3 \mathrm{~min}$ at $37{ }^{\circ} \mathrm{C}$, then stimulated for $5 \mathrm{~min}$ by collagen $(10 \mu \mathrm{g} / \mathrm{mL})$ and ADP $(5 \mu \mathrm{M})$ using an aggregometer (Chrono-Log Corporation, Havertown, PA, USA) at a constant stirring speed of 1,000 rpm.

To observe in vitro effects of WIB-801CE and cordycepin on resting human platelet aggregation, the aggregation of human washed platelets $\left(10^{8} / \mathrm{mL}\right)$ was performed as described above in the presence of WIB-801CE or cordycepin without agonists. But, collagen $(10 \mu \mathrm{g} / \mathrm{mL})$ was used as positive control. Each aggregation rate was determined as an increase in light transmission. The PPP for PRP aggregation, and platelet suspension buffer ( $\mathrm{pH}$ 6.9) for washed platelet aggregation were used as the reference (transmission 0 ) to regulate the base line of aggregometer. WIB-801CE and cordycepin were dissolved in distilled water.

\section{Ex vivo measurement of $\mathrm{TXB}_{2}$}

To investigate the effect on $\mathrm{TXA}_{2}$ production, the aggregation was terminated by adding ice-cold $5 \mathrm{mM}$ EDTA and 
$0.2 \mathrm{mM}$ indomethacin to inhibit subsequent conversion of AA to $\mathrm{TXA}_{2}$. The amounts of $\mathrm{TXB}_{2}$, a stable metabolite of $\mathrm{TXA}_{2}$, were determined using a $\mathrm{TXB}_{2}$ EIA kit according to the procedure described by the manufacturer.

\section{Ex vivo Western blot for analysis of protein phosphorylation}

Collagen- and ADP-activated rat PRP was centrifuged for $10 \mathrm{~min}$ at $1,300 \times \mathrm{g}$ under $4{ }^{\circ} \mathrm{C}$ to remove PPP and get platelet pellets. The platelets were suspended twice with suspension buffer $(138 \mathrm{mM} \mathrm{NaCl}, 2.7 \mathrm{mM} \mathrm{KCl}$, $12 \mathrm{mM} \mathrm{NaHCO}, 0.36 \mathrm{mM} \mathrm{NaH} \mathrm{PO}_{4}, 0.49 \mathrm{mM} \mathrm{MgCl}_{2}$, $5.5 \mathrm{mM}$ glucose, $0.25 \%$ gelatin, $\mathrm{pH}$ 7.4). The suspended platelets $(250 \mu \mathrm{L})$ were lysed by adding an equal volume $(250 \mu \mathrm{L})$ of lysis buffer [20 mM Tris- $\mathrm{HCl}, 150 \mathrm{mM} \mathrm{NaCl}$, $1 \mathrm{mM} \mathrm{Na} 2$ EDTA, $1 \mathrm{mM}$ EGTA, 1\% triton X-100, $2.5 \mathrm{mM}$ sodium pyrophosphate, $1 \mathrm{mM} \beta$-glycerophosphate (serine/ threonine phosphatase inhibitor), $1 \mathrm{mM} \mathrm{Na}_{3} \mathrm{VO}_{4}$ (ATPase, alkaline and acid phosphatase, and protein phosphotyrosine phosphatase inhibitor), $1 \mu \mathrm{g} / \mathrm{mL}$ leupeptin (serine and cysteine protease inhibitor), and $1 \mathrm{mM}$ phenylmethanesulfonyl fluoride (serine protease and acetylcholinesterase inhibitor), $\mathrm{pH}$ 7.5].

Platelet lysates were suspended in their equal volume of sodium dodecyl sulfate-polyacrylamide gel electrophoresis (SDS-PAGE) buffer (62.5 mM Tris- $\mathrm{HCl}, 10 \%$ glycerol, 1\% SDS, $1 \% \beta$-mercaptoethanol, $0.01 \%$ bromphenol blue, $\mathrm{pH}$ 6.8), then were boiled to completely denature the proteins for $5 \mathrm{~min}$. Aliquots containing $15 \mu \mathrm{g}$ of protein from each sample tube were subjected to SDS-PAGE (8\%, $1.5 \mathrm{~mm}$ gel) according to the method of Laemmli [20].

Proteins in the gel were transferred to PVDF membrane in the presence of transfer buffer $(25 \mathrm{mM}$ Tris- $\mathrm{HCl}$, 192 mM glycine, 20\% methanol, pH 8.3). PVDF membrane was washed one time for 5 min with Tris-buffered saline with tween $20(25 \mathrm{mM}$ Tris- $\mathrm{HCl}, 140 \mathrm{mM} \mathrm{NaCl}$, $2.7 \mathrm{mM} \mathrm{KCl}, 0.1 \%$ tween 20, pH 7.4), then was blocked with blocking buffer (25 mM Tris- $\mathrm{HCl}, 140 \mathrm{mM} \mathrm{NaCl}$, $2.7 \mathrm{mM} \mathrm{KCl}, 0.1 \%$ tween 20, 5\% skim milk, $\mathrm{pH}$ 7.4) for $1 \mathrm{~h}$ at room temperature, and subsequently was washed three times for $5 \mathrm{~min}$.

The protein phosphorylation was observed using Western blotting. The dilutions for 1st antibody (anti-phosphor-cPLA 2 , anti-phosphor-PLC ${ }_{\beta 3}$, anti-phosphor-PLC ${ }_{\gamma 2}$, anti-phosphor-p ${ }^{38}$ MAPK, anti-phosphor-ERK, anti-p ${ }^{38}$ MAPK, anti-ERK) and 2nd antibody (anti-rabbit IgG-HRP) were 1:1,000 and 1:10,000, respectively. The membranes were visualized using ECL. Blots were analyzed using the Quantity One, Ver. 4.5 (BioRad, Hercules, CA, USA).

\section{Ex vivo determination of $A A$ release}

To investigate the effect on AA release, the aggregation was terminated adding ice-cold $5 \mathrm{mM}$ EDTA and $0.2 \mathrm{mM}$ indomethacin to inhibit subsequent conversion of AA to
$\mathrm{TXA}_{2}$, and centrifuged with $200 \times \mathrm{g}$ at $4{ }^{\circ} \mathrm{C}$ for $10 \mathrm{~min}$. The supernatants were used for the assay of AA release. AA release was measured with a Synergy HT multi-model microplate reader (BioTek Instruments, Winooski, VT, USA) using AA release ELISA kit.

\section{Preparation of platelet lysates}

We prepared platelet lysates to determine ex vivo COX1 and TXAS activities. Collagen- and ADP-activated rat PRP was centrifuged for $10 \mathrm{~min}$ at $1,300 \times \mathrm{g}$ to remove PPP and get platelet pellets. The platelets were then suspended twice with suspension buffer $(138 \mathrm{mM} \mathrm{NaCl}$, $2.7 \mathrm{mM} \mathrm{KCl}, 12 \mathrm{mM} \mathrm{NaHCO}, 0.36 \mathrm{mM} \mathrm{NaH} \mathrm{PO}_{4}$, $0.49 \mathrm{mM} \mathrm{MgCl}_{2}, 5.5 \mathrm{mM}$ glucose, $0.25 \%$ gelatin, $\mathrm{pH} 7.4$ ). The suspended platelets in the presence of $1 \%$ protease inhibitor cocktail were sonicated ten times in sensitivity $100 \%$ for $20 \mathrm{~s}$ at $4{ }^{\circ} \mathrm{C}$ with a sonicator (HD 2070, Bandelin Electronic, Bandelin, Germany) to obtain platelet lysates. Next, the platelet lysates were centrifuged at $12,000 \times \mathrm{g}$ for $15 \mathrm{~min}$ at $4{ }^{\circ} \mathrm{C}$ to remove cell debris. The supernatant was used to measure COX-1 and TXAS activity.

\section{Ex vivo measurement of COX-1 activity}

Platelet lysates containing $10 \mu \mathrm{g}$ of protein were used. COX-1 activity was measured with a Synergy HT multimodel microplate reader (BioTek Instruments, Winooski, VT, USA) using COX-1 fluorescent activity assay kit according to the procedure described by manufacturer.

\section{Ex vivo measurement of TXAS activity}

Platelet lysates containing $20 \mu \mathrm{g}$ of protein were used. The reaction for assay of TXAS activity was initiated by the addition of TXAS substrate $\mathrm{PGH}_{2}$ and allowed to proceed for $1 \mathrm{~min}$ at $37{ }^{\circ} \mathrm{C}$. The reaction was terminated by the addition of $1 \mathrm{M}$ citric acid, then was neutralized with $1 \mathrm{~N} \mathrm{NaOH}$. The concentration of $\mathrm{TXA}_{2}$ was determined as $\mathrm{TXB}_{2}$, a stable metabolite of $\mathrm{TXA}_{2}$, which was measured with a Synergy HT multi-model microplate reader (BioTek Instruments, Winooski, VT, USA) using $\mathrm{TXB}_{2}$ EIA kit.

\section{Ex vivo determination of serotonin release}

To investigate the effect on serotonin release, the aggregation was centrifuged at $4{ }^{\circ} \mathrm{C}$ for $10 \mathrm{~min}$ at $200 \times \mathrm{g}$. The supernatants were used for the assay of serotonin release. Serotonin release was measured with a Synergy HT multi-model microplate reader (BioTek Instruments, Winooski, VT, USA) using serotonin ELISA kit.

\section{Ex vivo measurement of PT and APTT}

To investigate whether WIB-801CE shows anticoagulant characteristics, if any, has bleeding risk as side effect of anticoagulant [21], we measured PT and APTT, markers of blood coagulation. The PPP $(100 \mu \mathrm{L})$ was preincubated 
in a two-channel coagulator (Behnk Elektronik $\mathrm{GmbH} \&$ Co., KG, Norderstedt, Germany) cup (catalog number 95662, BioMérieux, Marcyl'Etoile, France) with gentle stirring for $1 \mathrm{~min}$ at $37{ }^{\circ} \mathrm{C}$. PT was determined as the time interval between the addition of PT reagent $(100 \mu \mathrm{L})$ to the PPP and the formation of a fibrin clot. After preincubation of PPP for APTT measurement, $100 \mu \mathrm{L}$ of APTT reagent was added to the PPP $(100 \mu \mathrm{L})$ and incubated for $3 \mathrm{~min}$ at $37{ }^{\circ} \mathrm{C}$. Following incubation, $100 \mu \mathrm{L}$ of $25 \mathrm{mM}$ $\mathrm{CaCl}_{2}$ was immediately added to the PPP containing APTT reagent. APTT was determined as the time required to form a fibrin clot.

\section{In vivo tail bleeding time assay}

We investigated whether WIB-801CE has bleeding risk, the side effect of antiplatelet substance [21]. WIB-801CE (200, $400 \mathrm{mg} / \mathrm{kg}-\mathrm{BW})$ and aspirin (100 mg/kg-BW), a positive control, were orally administered to mice once a day for five days. In this study, we used mice for measuring tail bleeding time according to the method of Kim and Lee [22]. After $5 \mathrm{~min}$ of the respective final administration, mice were anesthetized with zoletil $(40 \mathrm{mg} / \mathrm{kg}$, i.p.). The distal $0.5 \mathrm{~cm}$ segment of the tail was transected with operating knife, and immediately immersed in a tube containing $37{ }^{\circ} \mathrm{C}$ of saline. Tail bleeding time was determined as the time required to cause blood coagulation.

\section{In vivo evaluation of anti-acute pulmonary thromboembolism}

To confirm the endogenous antithrombotic effect, we used a mice model to generate acute pulmonary thromboembolism [23]. Mice were orally administered with WIB801CE (200, $400 \mathrm{mg} / \mathrm{kg}-\mathrm{BW})$, and aspirin (100 mg/kg-BW). After $1 \mathrm{~h}$ of respective administration, the mixture $(100 \mu \mathrm{L})$ of collagen $(300 \mu \mathrm{g} / \mathrm{kg}-\mathrm{BW})$ plus epinephrine $(30 \mu \mathrm{g} / \mathrm{kg}$ $\mathrm{BW}$ ) were injected via tail vein, and the rate of protection and mortality was observed for $15 \mathrm{~min}$, which were calculated as follow: 1) Protection rate $(\%)=[($ Number of tested mice - Number of dead mice)/Number of tested mice] $\times$ 100. 2) Mortality rate $(\%)=[$ Number of dead mice/Number of tested mice] $\times 100$. These experiments were proved by the Ethics Committee for animal experiments of Whanin Pharmaceutical Corporation (Suwon, Korea/15-NE-009).

\section{In vitro assay of platelet-mediated fibrin clot retraction}

We investigated whether WIB-801CE or cordycepin inhibits fibrin clot retraction, an index of thrombi formation [24]. Human PRP $250 \mu \mathrm{L}\left(10^{8}\right.$ platelets $\left./ \mathrm{mL}\right)$ were transferred into polyethylene tube to avoid clot adherence, then were preincubated with or without WIB-801CE or cordycepin for $10 \mathrm{~min}$ at $37{ }^{\circ} \mathrm{C}$, and subsequently stimulated with thrombin $(0.5 \mathrm{U} / \mathrm{mL})$ for $60 \mathrm{~min}$ at $37^{\circ} \mathrm{C}$. Pictures of fibrin clot were taken at 0 and 60 min using a digital camera, and its quantification was carried out by measurement of clot area using the NIH Image J Software (V1.46, National Institutes of Health, USA). Percentage of clot retraction was calculated as follows: Retraction (\%) by thrombin $=[1$ - (final clot area/initial clot area) $] \times 100$.

\section{In vitro nitric oxide assay}

To observe antiinflammatory effect of WIB-801CE, we used mouse leukemic macrophage RAW264.7 cells. RAW264.7 cells were obtained from the American Type Culture Collection (ATCC, Manassas, VA, USA), and were maintained at $37{ }^{\circ} \mathrm{C}$ in $5 \% \mathrm{CO}_{2}$ and $95 \%$ air in Dulbecco's Modified Eagle's Medium (GE Healthcare, Marlborough, USA) containing 10\% fetal bovine serum, and $1 \%$ penicillin-streptomycin solution. RAW264.7 cells $\left(5 \times 10^{4}\right.$ cells $)$ were preincubated for $30 \mathrm{~min}$ with or without WIB-801CE, or inducible nitric oxide synthase (iNOS) inhibitor amino guanidine (AG), and stimulated for $24 \mathrm{~h}$ by lipopolysaccharide $(10 \mathrm{ng} / \mathrm{mL})$. The supernatant was used for NO assay using Griess reagent. Equal volume of culture supernatant $(80 \mu \mathrm{L})$ and Griess reagent $(80 \mu \mathrm{L})$ were mixed. The absorbance of the mixture was measured at $540 \mathrm{~nm}$ using spectrophotometer (Spectramax 190, Molecular devices, LLC., Sunnyvale, CA, USA). Nitrite was used as standard of NO.

\section{Ex vivo nitric oxide assay}

To investigate the NO production, we used collagenand ADP-stimulated PRP obtained from rats administered with the WIB-801CE $(200,400 \mathrm{mg} / \mathrm{kg}-\mathrm{BW})$. The PRP was centrifuged at $4{ }^{\circ} \mathrm{C}$ for $10 \mathrm{~min}$ at $10,000 \times \mathrm{g}$ to get plasma. The plasma was incubated $1 \mathrm{~h}$ with $400 \mu \mathrm{L}$ methanol:diethylether (3:1 mixture $\mathrm{v} / \mathrm{v})$, and subsequently plasma proteins were precipitated by centrifuging at $4{ }^{\circ} \mathrm{C}$ for $10 \mathrm{~min}$ at $10,000 \times \mathrm{g}$. The supernatant was used for $\mathrm{NO}$ assay using Griess reagent. Equal volume of supernatant $(80 \mu \mathrm{L})$ and Griess reagent $(80 \mu \mathrm{L})$ were mixed. After $30 \mathrm{~min}$, absorbance of the mixture was measured at $540 \mathrm{~nm}$ using a Synergy HT multi-model microplate reader (BioTek Instruments, Winooski, VT, USA). Nitrite was used as standard of NO.

\section{In vitro determination of antioxidant activity}

To obtain antioxidant effect of WIB-801CE, we measured scavenging activity of free radical in DPPH according to the method $[25,26]$. DPPH was dissolved in $99 \%$ ethanol to make $200 \mu \mathrm{M}$ of solution. WIB-801CE and antioxidant $\mathrm{AC}$ were dissolved in distilled water. Equal volume of test substances and $\mathrm{DPPH}$ were mixed at room temperature. After $30 \mathrm{~min}$, the reduction in $\mathrm{DPPH}$ absorbance at $517 \mathrm{~nm}$ was measured using spectrophotometer (Optizen 2120UV, Mecasys, Korea). The scavenging activity of DPPH radicals by substances was determined using the following equation [26]: Scavenging activity (\%) = 
$\left[1-\left(\mathrm{A}_{\text {sample }} / \mathrm{A}_{\mathrm{DPPH}}\right)\right] \times 100$. The absorbance at $517 \mathrm{~nm}$ by 99\% ethanol, DPPH vehicle, and distilled water, vehicles of WIB-801CE and AC was 0.001 and 0.000 .

\section{Ex vivo measurement of cordycepin effect on rat platelet aggregation}

This experiment was performed to investigate the effect of cordycepin on ex vivo platelet aggregation. When cordycepin (15 mg/kg per day) was administered orally to the mice for 14 days, antitumor activity was known to observe [27]. Therefore, we selected 5 and $10 \mathrm{mg} / \mathrm{kg}-\mathrm{BW}$ per day of cordycepin in this experiment as moderate doses for administration. These doses are corresponded to about 36 and $72 \%$ of cordycepin in WIB-801CE (200 mg/kg-BW) that inhibited ex vivo rat platelet aggregation. Rats (Sprague-Dawley, male, $200 \mathrm{~g}$ ) were acclimatized for a week at a temperature of $24 \pm 1{ }^{\circ} \mathrm{C}$ and humidity of $55 \pm$ $5 \%$. Before oral administration of cordycepin, rats were fasted for $12 \mathrm{~h}$, then were fed with standard pellets diet (Purina Inc., Korea) had free access to water. Cordycepin (5 and $10 \mathrm{mg} / \mathrm{kg}$-BW) was orally administered to the rats one per day for seven days. Cordycepin were dissolved with distilled water. The experiments were proved by the Ethics Committee for Animal Experiments of Whanin Pharmaceutical Corporation (Suwon, Korea/15-NE-016 for rats). After the final respective administration, all rats were fasted for $24 \mathrm{~h}$, then were anesthetized with $20 \%$ urethane before sacrifice. PRP preparation, platelet aggregation, measurement were performed as described before.

\section{Protein assay}

To determine COX-1, TXAS activity, and protein phosphorylation, protein concentration was measured using bicinchoninic acid assay kit (Pierce Biotechnology, USA).

\section{Statistical analyses}

The experimental results are indicated as the mean \pm standard deviation accompanied by the number of observations. Data were determined by analysis of variance (ANOVA). If this analysis showed significant differences among the group means, then each group was compared by the Newman-Keuls method. Statistical analysis was carried out according to the SPSS 21.0.0.0 (SPSS, Chicago, IL, USA). $p<0.05$ was considered to be statistically significant.

\section{Results}

\section{Composition of cordycepin in WIB-801CE}

Because it is known that Cordyceps militaris, a source of WIB-801CE, has cordycepin (Fig. 1a) [28], we analyzed cordycepin of WIB-801CE with HPLC. As shown in Fig. 1b, peak 1 from WIB-801CE was observed at $19.988 \mathrm{~min}$ of the retention time, which was almost in accord with the retention time (19.980 $\mathrm{min}$ ) of pure cordycepin (Fig. 1c). This means that peak 1 is derived from cordycepin in WIB-801CE. The concentration of peak 1 in WIB$801 \mathrm{CE}$ corresponding to cordycepin was $69.30 \pm 0.20 \mathrm{mg} / \mathrm{g}$ WIB-801CE (about $6.93 \pm 0.02 \%$, Table 1). Whole fruiting body myelia of Cordyceps militaris is known to contain $0.16 \%$ of cordycepin, but whole fruiting body, stroma, and larva of Cordyceps sinensis do not contain cordycepin [29]. Therefore, the cordycepin content in WIB-801CE that we used in this study is very higher than those in whole fruiting body myelia of Cordyceps militaris, and in whole fruiting body, stroma, and larva of Cordyceps sinensis.

\section{In vitro effects of WIB-801CE and cordycepin on cytotoxicity against resting human platelets}

Cytotoxicity of drugs or substances is evaluated by cytosolic LDH leakage, which is different from platelet aggregation or granule secretion by platelet agonists, but is released upon damage of cell membrane [30-32]. Therefore, we investigated the effect of WIB-801CE on LDH leakage to human platelets. When human washed platelets $\left(10^{8} / \mathrm{mL}\right)$ were treated by membrane detergent triton $\mathrm{X}-100, \mathrm{LDH}$ was potently released up to $268.6 \pm 4.4 \mathrm{mU} /$ $10^{8}$ platelets, which is expressed as $100 \%$ (Fig. 1d). LDH leakage by WIB-801CE $(200,400 \mu \mathrm{g} / \mathrm{mL})$ was not occurred, and its degree $(8.6 \pm 1.4 \%)$ by $400 \mu \mathrm{g} / \mathrm{mL}$ of WIB-801CE was not significantly different from that $(7.3 \pm 0.4 \%)$ by resting platelets (Fig. 1d). Because WIB$801 \mathrm{CE}$ contains $6.93 \pm 0.02 \%$ of cordycepin (Table 1 ), to investigate whether cordycepin has cytotoxicity, we used concentrations $(56,112 \mu \mathrm{M})$ of cordycepin (MW 251.14) corresponding to cordycepin concentration $(6.93 \pm 0.02 \%)$ that contains in WIB-801CE $(200,400 \mu \mathrm{g} / \mathrm{mL})$. As the results, cordycepin $(56,112 \mu \mathrm{M})$ did not affect the release of $\mathrm{LDH}$ as compared with that $(7.3 \pm 0.4 \%)$ by resting platelets (Fig. 1d). These mean that WIB-801CE and cordycepin do not affect the cytotoxicity to human resting platelets.

Table 1 Content of cordycepin in WIB-801CE

\begin{tabular}{|c|c|c|c|c|c|}
\hline & Retention time (min) & Area $(\mathrm{mAU} \times \mathrm{s})$ & Concentration of sample $(\mu \mathrm{g} / \mathrm{mL})$ & Cordycepin content (\%) & Content (mg/g-WIB-801CE) \\
\hline Pure cordycepin & 19.980 & $2,949.35$ & 100.30 & - & - \\
\hline WIB-801CE Peak 1 & $19.988 \pm 0.011$ & $2,278.34 \pm 13.77$ & $1,006 \pm 0.32$ & $6.93 \pm 0.02$ & $69.30 \pm 0.20$ \\
\hline
\end{tabular}

The content of cordycepin in WIB-801CE was expressed using the following equation: Cordycepin content (\%) $=$ (area of peak $1 /$ area of pure cordycepin) $\times$ (concentration of pure cordycepin/concentration of WIB-801CE) $\times[(100 \%-\%$ of water content of cordycepin)/100\%] $\times(\%$ of purity of pure cordycepin/ $100 \%) \times 100 \%$. Water content of pure cordycepin was $8.18 \%$. Purity of pure cordycepin was $98.0 \%$. The data are given as the mean \pm standard deviation $(n=3)$ 
In vitro effects of WIB-801CE and cordycepin on activation of resting human platelets

Platelet activation is an index of platelet shape change, platelet aggregation and granule secretion, and is the cause of cardiovascular and cerebrovascular disease, and atherosclerosis [33-35]. Accordingly, if WIB-801CE activates resting platelets, unstimulated platelets, a question to evaluate the antiplatelet effects of WIB-801CE might be raised. Therefore, the effect of WIB-801CE and cordycepin on platelet activation was determined by measuring platelet aggregation in resting human platelets. As the results, a positive control collagen $(10 \mu \mathrm{g} / \mathrm{mL})$ activated platelets by increasing platelet aggregation up to $83.3 \pm 3.1 \%$ (Fig. 1e). However, WIB801CE (200, $400 \mu \mathrm{g} / \mathrm{mL})$ alone, and cordycepin (56, $112 \mu \mathrm{M})$ alone did not increased platelet aggregation (Fig. 1e), as compared with that $(1.0 \pm 1.0 \%)$ by resting platelets. It was evidenced that WIB-801CE and cordycepin alone do not affect the activation of resting human platelets.

\section{Ex vivo effects of WIB-801CE on platelet aggregation and $\mathrm{TXA}_{2}$ production}

It is known that the inhibition of collagen- and ADPinduced platelet aggregation is potential target to develop antithrombotic agent having antiplatelet characteristics $[36,37]$. Therefore, we used on collagen and ADP as agonists. When PRP $\left(10^{8} / \mathrm{mL}\right)$ from control was activated with collagen and ADP, the aggregation rate was increased up to $82.9 \pm 6.6 \%$ by collagen (Fig. 2a) and $78.7 \pm$ $4.9 \%$ by ADP (Fig. 2b). However, collagen- and ADPinduced rat platelet aggregation was significantly attenuated by WIB-801CE (200, $400 \mathrm{mg} / \mathrm{kg}-\mathrm{BW}$ ) (Fig. 2a and b). The inhibitory degrees by $200 \mathrm{mg} / \mathrm{kg}-\mathrm{BW}$ were $13.0 \%$ to that by collagen (Fig. 2a) and $10.9 \%$ against that by ADP (Fig. 2b).

We investigated next whether WIB-801CE involves in inhibition of $\mathrm{TXA}_{2}$ production to attenuate collagen- and ADP-induced rat platelet aggregation. When PRP $\left(10^{8} / \mathrm{mL}\right)$ from control was activated by collagen and ADP, the $\mathrm{TXA}_{2}$ (determined as $\mathrm{TXB}_{2}$, a stable metabolite of $\mathrm{TXA}_{2}$ ) was increased to $615.0 \pm 11.5 \mathrm{ng} / 10^{8}$ platelets (Fig. 2c) by collagen and $11.5 \pm 1.6 \mathrm{ng} / 10^{8}$ platelets by ADP (Fig. 2d). However, collagen- and ADP-produced $\mathrm{TXA}_{2}$ were inhibited by WIB-801CE (Fig. 2c and d). The inhibitory degrees by $200 \mathrm{mg} / \mathrm{kg}$-BW were $30.7 \%$ against that by collagen (Fig. 2c) and $37.3 \%$ to that by ADP (Fig. 2d). WIB-801CE (400 mg/ kg-BW) inhibited weakly ADP-induced platelet aggregation

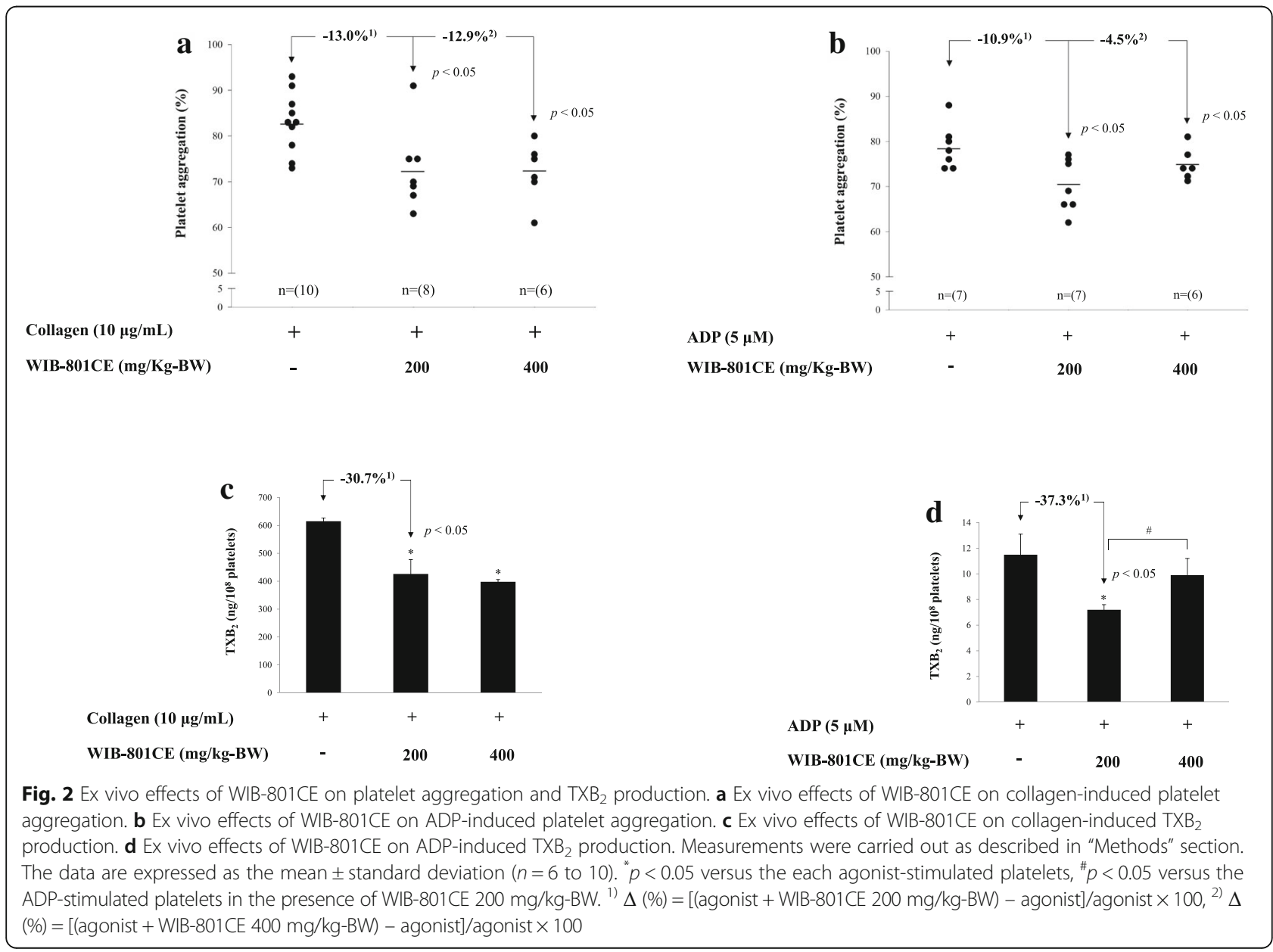


(Fig. 2b) and TXA 2 production (Fig. 2d) as compared with those by WIB-801CE (200 mg/kg-BW).

\section{Ex vivo effects of WIB-801CE on phosphorylation of $\mathrm{PLC}_{\beta 3}, \mathrm{PLC}_{\gamma 2}, \mathrm{CPLA}_{2}$, release of AA, and activity of COX-1 and TXAS}

The reduction of $\mathrm{TXA}_{2}$ by WIB-801CE is connected to either inhibition of $\mathrm{AA}$ release enzymes $\left(\mathrm{PLC}_{\beta}, \mathrm{PLC}_{\gamma}\right.$ and ${ }_{c P L A}$ ) or AA utilization enzymes (COX-1, TXAS). When PRP $\left(10^{8} / \mathrm{mL}\right)$ from WIB-801CE $(200,400 \mathrm{mg} / \mathrm{kg}-\mathrm{BW})$ rats were activated by collagen and ADP, phosphorylation of $\operatorname{PLC}_{\beta 3}\left(\operatorname{Ser}^{1105}\right), \mathrm{PLC}_{\gamma 2}\left(\mathrm{Tyr}^{1217}\right)$ and $\mathrm{CPLA}_{2}\left(\mathrm{Ser}^{505}\right)$ were increased (Fig. $3 a$ and b, lane 2), but $\operatorname{PLC}_{\beta 3}\left(\operatorname{Ser}^{537}\right.$ ) was not changed as compared with those (Fig. $3 a$ and b, lane 1) by resting platelets. WIB-801CE did not inhibit these phosphorylation (Fig. 3a and b, lane 3 and 4). These results are indicated that WIB-801CE does not attenuate collagen- and ADP-induced the activities of $\mathrm{CPLA}_{2}, \mathrm{PLC}_{\beta 3}$ and $\mathrm{PLC}_{\gamma 2}$, and the direct AA release by $\mathrm{CPLA}_{2}$, but may involve in inhibition of the indirect AA release by $\mathrm{PLC}_{\beta 3} /$ diacylglycerol (DG)- and monoacylglycerol-lipase pathway $[4,5,11,12]$.

With this possibility, we investigated whether WIB801CE affects AA release. Collagen and ADP released AA up to $91.5 \pm 0.7 \mathrm{ng} / 10^{8}$ platelets (Fig. 3c) and $49.4 \pm 0.4 \mathrm{ng} /$ $10^{8}$ platelets (Fig. 3d) in control, respectively. However, when PRP $\left(10^{8} / \mathrm{mL}\right)$ from WIB-801CE $(200,400 \mathrm{mg} / \mathrm{kg}$ $\mathrm{BW})$ rats were activated by collagen and ADP, the levels of AA release were significantly decreased as compared with those by control (Fig. 3c and d). The inhibitory degrees by $200 \mathrm{mg} / \mathrm{kg}$-BW were $29.0 \%$ (Fig. 3c) against that by collagen and $35.2 \%$ (Fig. 3d) against that by ADP.

WIB-801CE did not completely inhibit AA release (Fig. 3c and $\mathrm{d}$ ), which means that collagen- and ADP-released AA may be subsequently metabolized to $\mathrm{TXA}_{2}$ via COX-1/ TXAS pathway. Therefore, we investigated whether WIB801CE inhibits ex vivo activity of COX-1 or TXAS. Collagenand ADP-induced COX-1 activities as compared with those by resting platelets, but these were not attenuated by WIB$801 \mathrm{CE}$ (200, $400 \mathrm{mg} / \mathrm{kg}-\mathrm{BW})$ (Fig. 3e). Collagen and ADP induced TXAS activities as compared with those by resting platelets (Fig. 3f and g). However, collagen-induced TXAS activity $(18.8 \pm 1.9 \mathrm{ng} /$ protein- $\mathrm{mg} / \mathrm{min})$ was reduced to $34.6 \% \quad(12.3 \pm 1.1 \mathrm{ng} /$ protein-mg/min $)$ by WIB-801CE (200 mg/kg-BW) (Fig. 3f). ADP-induced TXAS activity (5.9 $\pm 0.5 \mathrm{ng} /$ protein- $\mathrm{mg} / \mathrm{min})$ was also attenuated to $27.1 \%(4.3$ $\pm 0.5 \mathrm{ng} /$ protein-mg $/ \mathrm{min})$ by WIB-801CE $(200 \mathrm{mg} / \mathrm{kg}-\mathrm{BW})$ (Fig. 3g). WIB-801CE (400 mg/kg-BW) inhibited weakly ADP-induced AA release (Fig. 3d) and TXAS activity (Fig. 3g) as compared with those by WIB-801CE (200 mg/kg-BW).

\section{Ex vivo effects of WIB-801CE on serotonin release}

Next, we investigated the effect of WIB-801CE on serotonin release as an index of granule secretion. Collagen and
ADP elevated serotonin release up to $224.5 \pm 4.3 \mathrm{ng} / 10^{8}$ platelets (Fig. 4a) and $290.1 \pm 9.6 \mathrm{ng} / 10^{8}$ platelets (Fig. 4b), respectively. On the contrary, collagen- and ADP-released serotonin levels were reduced by WIB-801CE (200, $400 \mathrm{mg} / \mathrm{kg}-\mathrm{BW}$ ) (Fig. 4a and b). The inhibitory degrees by $200 \mathrm{mg} / \mathrm{kg}-\mathrm{BW}$ were $66.3 \%$ to that by collagen (Fig. 4a) and $60.2 \%$ against that by ADP (Fig. 4b). WIB-801CE (400 mg/kg-BW) weakly inhibited ADP-induced serotonin release (Fig. 4b) as compared with that by WIB801CE (200 mg/kg-BW).

\section{Ex vivo effects of WIB-801CE on $\mathrm{p}^{38 \text { MAPK }}$ - and ERK-phosphorylation}

It is well reviewed that platelets contain MAPKs such as $\mathrm{p}^{38}$, ERK (1/2), and c-Jun $\mathrm{N}$-terminal kinase [38]. These are activated by various agonists (i.e. collagen, ADP, thrombin, von Willebrand factor, fibrinogen) and subsequently stimulate various enzymes [myosin light chain kinase (MLCK), DG-lipase, cPLA 2 , COX-1] associated with platelet activation $[9,10,38-46]$. Of MAPKs, $\mathrm{p}^{38}$ MAPK and ERK2 stimulate MLCK [38-41] to release serotonin, DG-lipase [45] and cPLA $2[9,10,38,42,43]$ to produce $\mathrm{AA}, \mathrm{TXA}_{2}$ precursor. In this study, to observe the relationship with the results that WIB-801CE inhibited collagenand ADP-induced $\mathrm{TXA}_{2}$ production (Fig. $2 \mathrm{c}$ and d), AA release (Fig. $3 \mathrm{c}$ and d) and serotonin release (Fig. $4 \mathrm{a}$ and b), we investigated whether WIB-801CE inhibits the phosphorylation of $\mathrm{p}^{38 \text { MAPK }}$ and ERK.

Collagen and ADP increased potently $\mathrm{p}^{38}$ MAPK phosphorylation (Fig. 5a and b, lane 2) as compared with those by resting platelets (Fig. $5 \mathrm{a}$ and b, line 1), respectively. However, these were diminished by WIB-801CE (200, $400 \mathrm{mg} / \mathrm{kg}-\mathrm{BW})$ (Fig. 5a and b, lane 3, 4). WIB801CE (200 mg/kg-BW) inhibited $\mathrm{p}^{38}$ MAPK phosphorylation up to $52.6 \%$ against that by collagen (Fig. 5a, lane 3 ) and $80.0 \%$ against that by ADP (Fig. 5b, lane 3).

Collagen and ADP elevated potently ERK2 $(42 \mathrm{kDa})$ phosphorylation (Fig. 5c and d, lane 2) as compared with those by resting platelets (Fig. $5 \mathrm{c}$ and d, line 1), respectively. However, these were also vanished by WIB-801CE (200, $400 \mathrm{mg} / \mathrm{kg}-\mathrm{BW}$ ) (Fig. 5c and d, lane 3, 4). WIB801CE (200 mg/kg-BW) inhibited ERK2 (42 kDa) phosphorylation up to $62.5 \%$ against that by collagen (Fig. $5 \mathrm{c}$, lane 3 ) and $81.8 \%$ against that by ADP (Fig. 5 d, lane 3 ). WIB-801CE $(400 \mathrm{mg} / \mathrm{kg}-\mathrm{BW})$ inhibited weakly phosphorylation of both $\mathrm{p}^{38 \text { MAPK }}$ and ERK2 (Fig. $5 \mathrm{~b}$ and $\mathrm{d}$, lane 4 ) as compared with those (Fig. $5 \mathrm{~b}$ and d, lane 3 ) by WIB-801CE $(200 \mathrm{mg} / \mathrm{kg}-\mathrm{BW})$ in ADP-activated platelets.

\section{Ex vivo and in vivo effects of WIB-801CE on blood coagulation and tail bleeding time}

Bleeding is connected to the attenuation of platelet aggregation and blood coagulation, and the inhibition of thrombosis $[8,21,47,48]$. Accordingly, we investigated the effects 


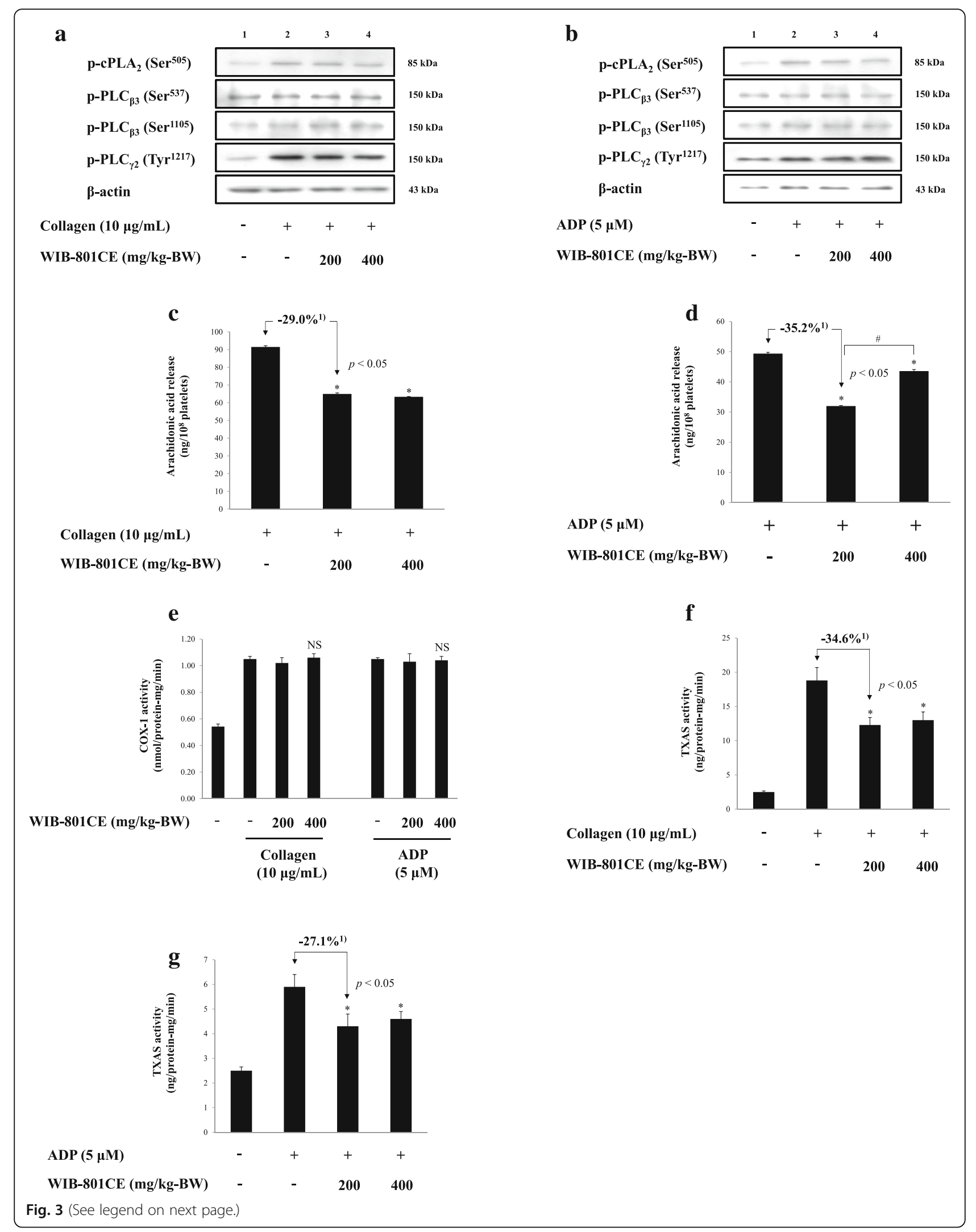


(See figure on previous page.)

Fig. 3 Ex vivo effects of WIB-801CE on phosphorylation of $C P L A_{2}, P_{2} C_{\beta 3}, P L C_{\gamma 2}$, release of AA, and activity of COX-1 and TXAS. a Ex vivo effects of

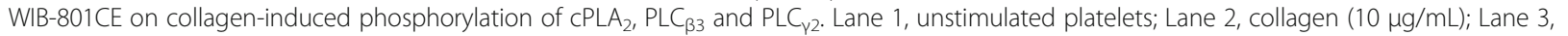
collagen $(10 \mu \mathrm{g} / \mathrm{mL})+$ WIB-801CE $(200 \mathrm{mg} / \mathrm{kg}-B W)$; Lane 4, collagen $(10 \mu \mathrm{g} / \mathrm{mL})+$ WIB-801CE $(400 \mathrm{mg} / \mathrm{kg}-\mathrm{BW})$. $\mathbf{b}$ Ex vivo effects of WIB-801CE on ADP-induced phosphorylation of $C P L A_{2}, P_{C_{33}}$ and PLC $C_{\gamma 2}$. Lane 1, unstimulated platelets; Lane 2, ADP $(5 \mu M)$; Lane 3, ADP $(5 \mu M)+$ WIB-801CE (200 mg/kg-BW); Lane 4, ADP (5 $\mu \mathrm{M})+$ WIB-801CE (400 mg/kg-BW). c Ex vivo effects of WIB-801CE on collagen-induced arachidonic acid release. d Ex vivo effects of WIB-801CE on ADP-induced arachidonic acid release. e Ex vivo effects of WIB-801CE on COX-1 activity $\mathbf{f}$ Ex vivo effects of WIB-801CE on collagen-induced TXAS activity. $\mathbf{g}$ Ex vivo effects of WIB-801CE on ADP-induced TXAS activity. Measurements were carried out as described in "Methods" section. The data are expressed as the mean \pm standard deviation $(n=4) .{ }^{*} p<0.05$ versus each agonist-stimulated platelets. NS, not significant versus the each agonist-stimulated platelets, ${ }^{\#} p<0.05$ versus the ADP-stimulated platelets in the presence of WIB-801CE $200 \mathrm{mg} / \mathrm{kg}-\mathrm{BW}$. ${ }^{1)} \Delta(\%)=[($ agonist + WIB801CE $200 \mathrm{mg} / \mathrm{kg}-\mathrm{BW}$ ) - agonist]/agonist $\times 100$

of WIB-801CE on ex vivo blood coagulation time (PT, APTT) and in vivo tail bleeding time as indexes of bleeding. As shown in Table 2, both ex vivo PT and APTT were not significantly prolonged by PPP from WIB-801CE rats as compared with those (PT, $13.2 \pm 2.3 \mathrm{~s}$; APTT, $26.2 \pm$ $4.1 \mathrm{~s})$ by normal. Warfarin $(1 \mathrm{mg} / \mathrm{kg}-\mathrm{BW})$ infinitely prolonged PT and APTT (Table 2).

With regard to the effects of WIB-801CE on tail bleeding time, WIB-801CE (200, $400 \mathrm{mg} / \mathrm{kg}-\mathrm{BW})$ significantly prolonged from $125.3 \pm 17.0 \mathrm{~s}$ by control to $264.8 \pm 79.0 \mathrm{~s}$ and $360.3 \pm 83.8 \mathrm{~s}$, respectively (Table 3 ). Aspirin (100 mg/kg-BW) also prolonged tail bleeding time to $1,800.0 \pm 0.0 \mathrm{~s}$ (Table 3$)$. Aspirin $(100 \mathrm{mg} / \mathrm{kg}$ $\mathrm{BW}$ ) potently prolonged bleeding time to $1,336.5 \%$, on the other hand, WIB-801CE (200, $400 \mathrm{mg} / \mathrm{kg}-\mathrm{BW})$ prolonged it up to $111.4 \%$ and $187.5 \%$ as compared with that $(125.3 \pm 17.0 \mathrm{~s})$ by control, respectively (Table 3$)$.

\section{In vivo effects of WIB-801CE on acute pulmonary thromboembolism}

Because antiplatelet drugs play an important role in protection of thrombus formation, we investigated whether WIB-801CE, inhibiting ex vivo platelet aggregation, has also a protective effect on endogenous thrombus formation. In this study, in vivo venous antithrombotic effect of WIB-
801CE was estimated using collagen plus epinephrineinduced acute pulmonary thromboembolism mouse model [23, 49-51]. As shown in Table 4, when the mixture of collagen plus epinephrine was treated to mice, the protection rate was $4.2 \%$ against acute pulmonary thromboembolism, and the mortality rate was $95.8 \%$. However, in WIB-801CEtreated mice, the protection degree from a pulmonary thromboembolism was increased to $25.0 \%$ by WIB-801CE (200 mg/kg-BW), and $35.0 \%$ by WIB- $801 \mathrm{CE}(400 \mathrm{mg} / \mathrm{kg}$ $\mathrm{BW}$ ) in a dose dependent manner (Table 4). In aspirin $(100 \mathrm{mg} / \mathrm{kg}-\mathrm{BW})$-treated mice, the protection degree from a pulmonary thromboembolism was increased up to $35.0 \%$, and the mortality was decreased to $65.0 \%$, which were equal to those by WIB-801CE (400 mg/kg-BW)-treatment (Table 4). These mean that WIB-801CE is actually valid to protect venous thromboembolism like aspirin.

\section{In vitro effects of WIB-801CE and cordycepin on fibrin clot retraction}

Fibrin clot retraction is a final index of platelet aggregationmediated thrombotic formation, and is resulted from interaction of fibrin-platelet [24]. Thrombin stimulated the retraction of fibrin clot (Fig. 6a, dotted circle), but WIB801CE $(200,400 \mu \mathrm{g} / \mathrm{mL})$ inhibited it in a dose dependent manner (Fig. 6a and b). WIB-801CE (200 $\mu \mathrm{g} / \mathrm{mL})$ inhibited 


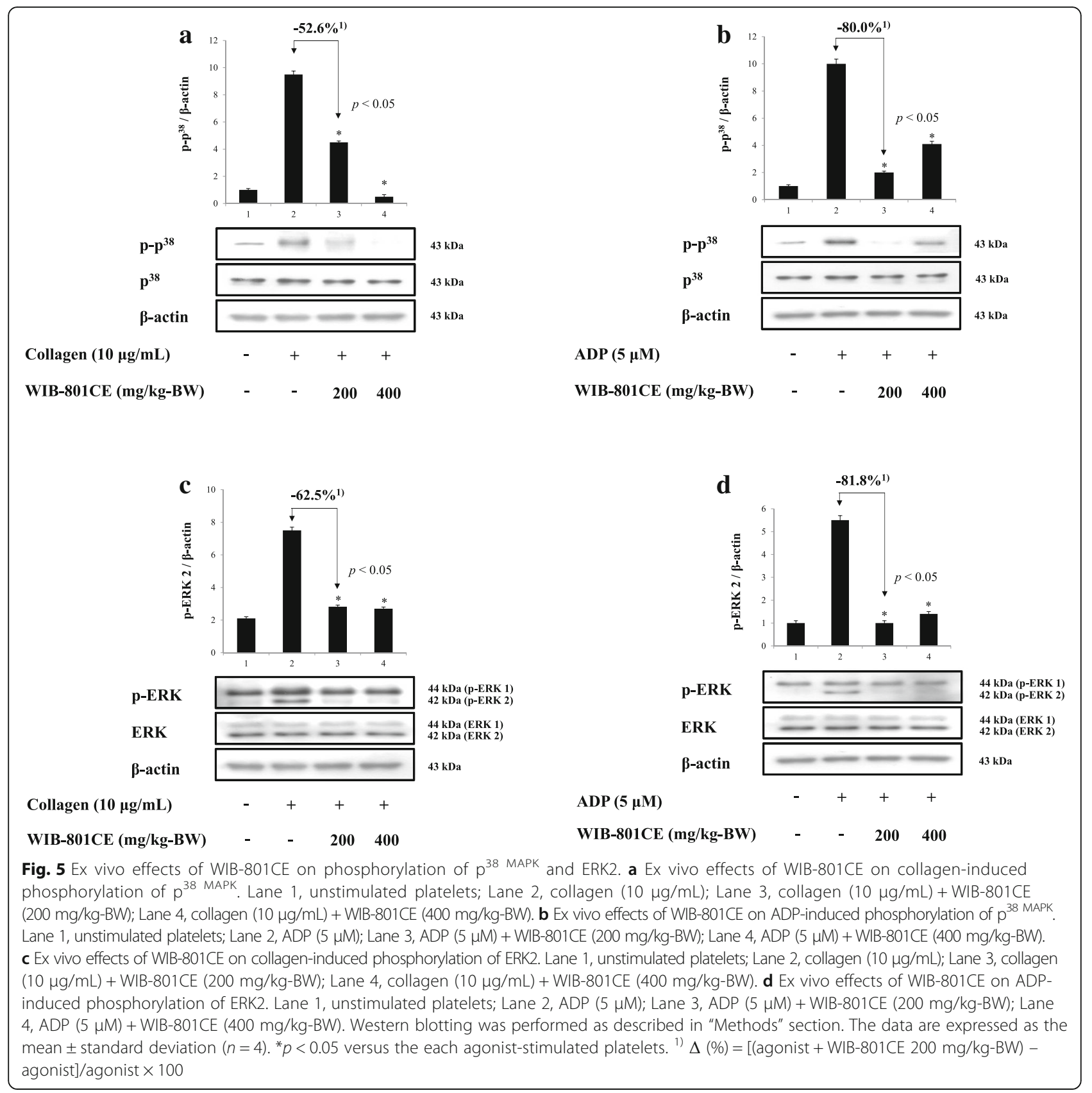

thrombin-induced fibrin clot retraction up to $74.3 \%$ (Fig. 6b). Cordycepin $(56,112 \mu \mathrm{M})$ corresponding to dose $(200,400 \mu \mathrm{g} / \mathrm{mL})$ of WIB-801CE attenuated thrombininduced fibrin clot retraction in a dose dependent manner (Fig. 6a and b). Cordycepin $(56 \mu \mathrm{M})$ corresponding to $200 \mu \mathrm{g} / \mathrm{mL}$ of WIB-801CE inhibited thrombin-induced fibrin clot retraction $(14.4 \pm 5.1 \%)$ up to $59.1 \%$ (Fig. $6 \mathrm{~b}$ ).

\section{In vitro and ex vivo effects of WIB-801CE on NO production}

It is well known that monocytes/macrophages and neutrophils produce various inflammatory mediators (i.e. NO,
Table 2 Ex vivo effects of WIB-801CE-administration on blood coagulation

\begin{tabular}{lllll}
\hline Animal group & Dose $(\mathrm{mg} / \mathrm{kg}-\mathrm{BW})$ & PT $(\mathrm{s})$ & APTT $(\mathrm{s})$ & $\mathrm{N}$ \\
\hline Normal & N.D. & $13.2 \pm 2.3$ & $26.2 \pm 4.1$ & 8 \\
WIB-801CE & 200 & $17.7 \pm 4.9^{\mathrm{NS}}$ & $26.3 \pm 3.9^{\mathrm{NS}}$ & 8 \\
& 400 & $16.8 \pm 3.2^{\mathrm{NS}}$ & $26.0 \pm 3.9^{\mathrm{NS}}$ & 8 \\
Warfarin & 1 & $\infty$ & $\infty$ & 6 \\
\hline
\end{tabular}

The results were expressed as the mean \pm standard deviation $(n=8$ or 6$)$. $\infty$, no coagulation; NS not significant versus normal; N.D normal diet, $N$ number of tested rats; $B W$ body weight, $P T$ prothrombin time, APTT activated partial thromboplastin time $s$, second 
Table 3 In vivo effects of WIB-801CE on tail bleeding time

\begin{tabular}{lllll}
\hline Animal group & Dose $(\mathrm{mg} / \mathrm{kg}-\mathrm{BW})$ & Tail bleeding time $(\mathrm{s})$ & $\Delta(\%)$ & $\mathrm{N}$ \\
\hline Control & Saline & $125.3 \pm 17.0$ & 0 & 8 \\
WIB-801CE & 200 & $264.8 \pm 79.0^{*}$ & 111.3 & 8 \\
& 400 & $360.3 \pm 83.8^{* *}$ & 187.5 & 8 \\
Aspirin & 100 & $1,800.0 \pm 0.0^{* *}$ & $1,336.5$ & 5 \\
\hline
\end{tabular}

The results were expressed as the mean \pm standard deviation $(n=8$ or 5$) .{ }^{*} p<0.05$ compared with control, ${ }^{* *} p<0.001$ compared with control. $N$ number of tested mice, $B W$ body weight, $s$, second $\Delta(\%)=[($ WIB-801CE or aspirin $)$ control $] /$ control $\times 100$

prostaglandin $\mathrm{E}_{2}$ ), and subsequently activate platelets to generate atherothrombosis $[52,53]$. In recent, it is also reported that neutrophil-produced $\mathrm{NO}$ activates platelet in chronic renal failure [54]. Accordingly, we investigated whether WIB-801CE inhibits in vitro NO production in RAW264.7 macrophage cells. As shown in Fig. 7a, lipopolysaccharide (LPS), an activator of macrophages, potently produced $\mathrm{NO}$ as compared with that of normal. However, WIB-801CE dose (15 to $50 \mu \mathrm{g} / \mathrm{mL})$-dependently attenuated LPS-elevated NO production (Fig. 7a). iNOS inhibitor AG potently inhibited NO production (Fig. 7a).

The ex vivo NO levels in plasma from PRP of control (Fig. 7b, lane 2, 5) and WIB-801CE (200, $400 \mathrm{mg} / \mathrm{kg}-\mathrm{BW})$ stimulated with collagen (Fig. $7 \mathrm{~b}$, lane 3,4 ) and ADP (Fig. 7b, lane 6, 7) were not changed as compared with that (Fig. 7b, lane 1) in plasma from control rat, in the absence of ADP, collagen and WIB-801CE. These mean that WIB-801CE (200, $400 \mathrm{mg} / \mathrm{kg}-\mathrm{BW})$ did not at least activate inflammatory iNOS in leukocytes (i.e. monocyte, macrophage, neutrophil) in vivo. Otherwise, the ex vivo NO levels would be increased in plasma from WIB-801CE (200, $400 \mathrm{mg} / \mathrm{kg}-\mathrm{BW})$ stimulated with collagen and ADP.

\section{In vitro effects of WIB-801CE on free radical scavenging activity}

Reactive oxygen species (ROS) activate platelets and thrombogenesis [55-57]. In this study, we investigated whether WIB-801CE has an antioxidant effect scavenging ROS, which was evaluated as scavenging activity of free radical in $\mathrm{DPPH}$, a stable free-radical molecules [25]. AC, a positive control, potently reduced the absorbance of DPPH. This means that AC has antioxidant effect by scavenging free radical in DPPH [25]. WIB$801 \mathrm{CE}$ also attenuated the absorbance of $\mathrm{DPPH}$ in a dose dependent manner (Fig. 7c). This result is indicated that WIB-801CE has antioxidant effect by scavenging free radical in DPPH like AC.

\section{Ex vivo effects of cordycepin on platelet aggregation}

As shown in Table 5, When PRP $\left(10^{8} / \mathrm{mL}\right)$ from control, was activated with $\mathrm{ADP}(10 \mu \mathrm{M})$, the aggregation rate was increased up to $75.7 \pm 0.6 \%$. But ADP-induced platelet aggregation significantly decreased by cordycepin (5, $10 \mathrm{mg} / \mathrm{kg}-\mathrm{BW}$ ) (Table 5). The inhibitory degree by $5 \mathrm{mg} / \mathrm{kg}-\mathrm{BW}$ was $31.7 \%$. This is higher than that $(10.9 \%)$ by WIB-801CE (200 mg/kg-BW) (Fig. 2b).

\section{Discussion}

WIB-801CE and its component cordycepin did not affect the cytotoxicity (determined as LDH leakage) and platelet activation (determined as platelet aggregation) to resting human platelets in vitro. These mean that there is no problem to evaluate the antiplatelet effects of WIB-801CE ex vivo. It is well established that various agonists (i.e. collagen, ADP, thrombin)-produced $\mathrm{TXA}_{2}$ generates circulatory disorder such as thrombosis, atherosclerosis, and myocardial infarction by stimulating platelet aggregation, vasoconstriction, and bronchoconstriction $[5,58,59]$. Therefore, it is essential to inhibit platelet aggregation and $\mathrm{TXA}_{2}$ production to prevent circulatory disorder in blood vessel. WIB-801CE attenuated ex vivo collagen- and ADP-induced platelet aggregation and $\mathrm{TXA}_{2}$ production.

These results were connected to the ex vivo inhibition of AA release and TXAS activity by WIB-801CE in collagen- and ADP-activated platelets. WIB-801CE did not also inhibit ex vivo collagen- and ADP-induced $\mathrm{PLC}_{\beta 3}$ $\left(\operatorname{Ser}^{537}\right.$, Ser $\left.^{1105}\right), \mathrm{PLC}_{\gamma 2}\left(\mathrm{Tyr}^{1217}\right)$ phosphorylation. These mean that WIB-801CE would produce DG from phosphatidylinositol 4,5-bisphosphate in collagen- and ADPactivated platelets. DG is known to hydrolyze by $\mathrm{p}^{38}$ MAPK-activated DG-lipase to release AA [45]. If so, it is considered that WIB-801CE may attenuate AA release by inhibiting $\mathrm{p}^{38}$ MAPK/DG-lipase pathway [45] without affecting inhibition of $\mathrm{CPLA}_{2}$ and $\mathrm{PLC}_{\beta 3}[9,10,42,43]$. Because agonist-produced $\mathrm{TXA}_{2}$ enforces thrombus formation as a positive promoter $[5,58,59]$, a compound or substance that inhibits the activity of COX-1 or TXAS, the production of $\mathrm{TXA}_{2}$ or the action of

Table 4 In vivo effects of WIB-801CE on acute pulmonary thromboembolism

\begin{tabular}{|c|c|c|c|c|c|}
\hline Animal group & Dose (mg/kg-BW) & No. of tested mice ${ }^{(}$ & No. of dead ${ }^{(2)}$ & Protection (\%) & Mortality (\%) \\
\hline Control & - & 24 & 23 & 4.2 & 95.8 \\
\hline \multirow[t]{2}{*}{ WIB-801CE } & 200 & 20 & 15 & 25.0 & 75.0 \\
\hline & 400 & 20 & 13 & 35.0 & 65.0 \\
\hline Aspirin & 100 & 20 & 13 & 35.0 & 65.0 \\
\hline
\end{tabular}

Protection $(\%)=($ (1) - (2) $/(1) \times 100$, Mortality $(\%)=(2) /(1) \times 100$. No., number of tested mice; BW, body weight 


\section{a}

\section{Incubation time}

0 min

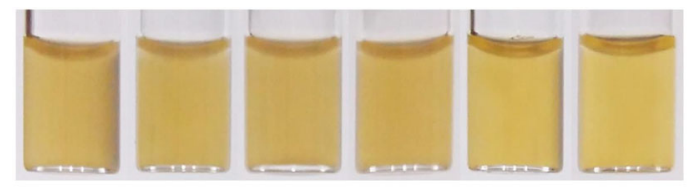

$60 \mathrm{~min}$

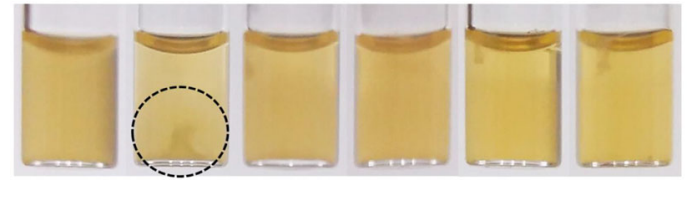

Thrombin $(0.5 \mathrm{U} / \mathrm{mL})$

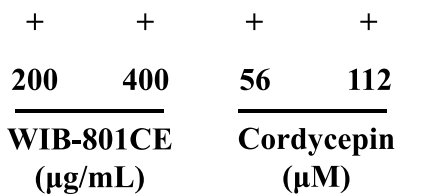

b

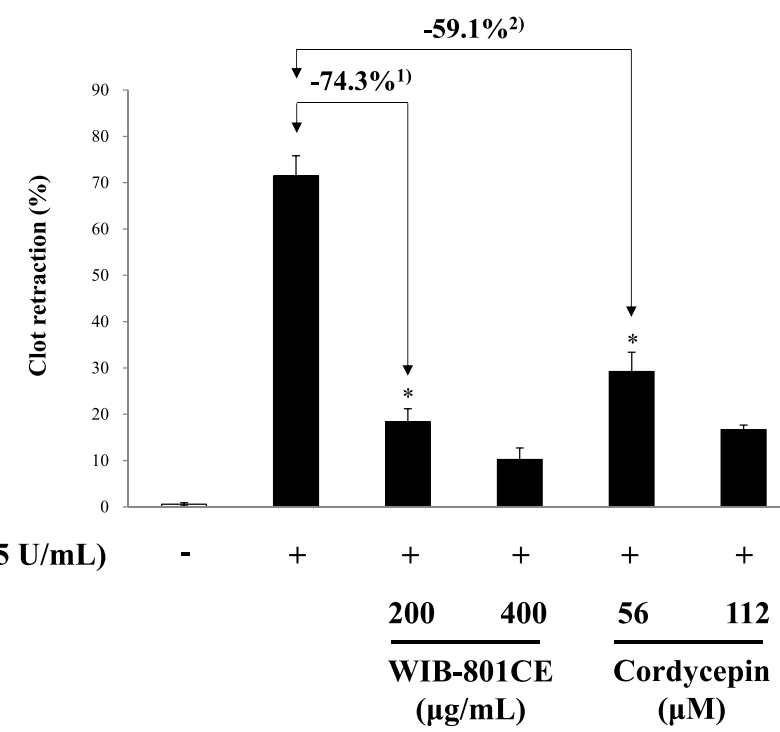

Fig. 6 In vitro effects of WIB-801CE and cordycepin on fibrin clot retraction. a In vitro effects of WIB-801CE and cordycepin on thrombin-induced fibrin clot. $\mathbf{b}$ In vitro effects of WIB-801CE and cordycepin on thrombin-retracted clot retraction (\%). Quantification of fibrin clot retraction was performed as described in "Methods" section. The data are expressed as the mean \pm standard deviation $(n=4) .{ }^{*} p<0.05$ versus the thrombin-stimulated platelets. ${ }^{1)}$ $\Delta(\%)=[($ agonist + WIB-801CE $200 \mu \mathrm{g} / \mathrm{mL})-$ agonist $] /$ agonist $\times 100,{ }^{2)} \Delta(\%)=[($ agonist + cordycepin $56 \mu \mathrm{M})-$ agonist $] /$ agonist $\times 100$

TXA $_{2}$ is evaluated as antithrombotic agents. Many studies have been performed to discover therapeutic agents that can counteract the effects of $\mathrm{TXA}_{2}$. Various phytochemicals (i.e. epigallocatechin-3-gallate, caffeic acid, chlorogenic acid, caffedymine, sanguinarine) are known to inhibit COX-1 rather than TXAS to suppress the $\mathrm{TXA}_{2}$ production in vitro or ex vivo [60-65]. However, WIB-801CE inhibited the activity of TXAS rather than COX-1 ex vivo, which reflects that WIB-801CE inhibits the $\mathrm{TXA}_{2}$ production pathway from $\mathrm{PGH}_{2}$ rather than prostaglandin $G_{2}$ production pathway from AA. In this study, we showed that WIB-801CE may involve in down-regulation of both $\mathrm{p}^{38}$ MAPK phosphorylation to vanish the AA supply from DG and TXAS activity to block the $\mathrm{TXA}_{2}$ production from $\mathrm{PGH}_{2}$ ex vivo. Therefore, it is apparent that WIB-801CE can be beneficially used to prevent the $\mathrm{TXA}_{2}$-mediated thrombus formation in vivo.

It is well known that agonist-released serotonin stimulates irreversibly platelet aggregation, and subsequently causes the thrombosis as well as $\mathrm{TXA}_{2}$ [66-68]. WIB801CE inhibited collagen- and ADP-induced serotonin release ex vivo, which reflects that WIB-801CE can inhibit the irreversible platelet aggregation in vivo. WIB801CE potently inhibited ex vivo the phosphorylation of $\mathrm{p}^{38 \mathrm{MAPK}}$ and ERK2 $(42 \mathrm{kDa})$, but not $\mathrm{Ca}^{2+}$-dependent 


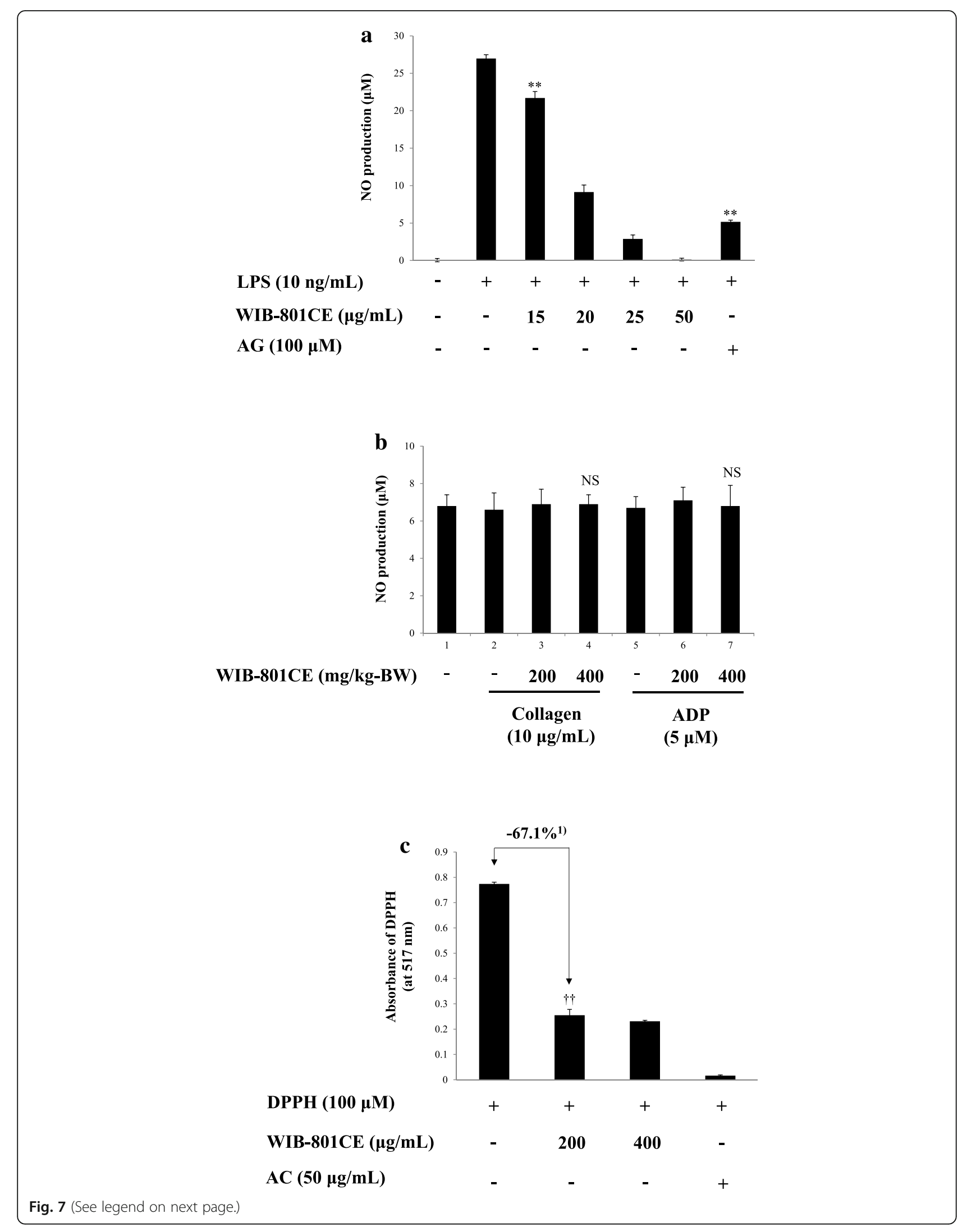


(See figure on previous page.)

Fig. 7 Effects of WIB-801CE on NO production, and antioxidation activity. a In vitro effects of WIB-801CE on LPS-induced NO production. b Ex vivo effects of WIB-801CE on collagen- and ADP-induced NO production. c In vitro effects of WIB-801CE on antioxidation activity. Measurements were carried out as described in "Methods" section. The data are expressed as the mean \pm standard deviation $(n=4){ }^{* *} p<0.001$ versus LPS-stimulated RAW264.7 cells. ${ }^{\dagger \dagger} p<0.001$ versus the DPPH. NS, not significant versus the each agonist-stimulated platelets. ${ }^{1)} \Delta(\%)=[($ DPPH + WIB-801CE $200 \mu \mathrm{g} / \mathrm{mL})-$ DPPH]/DPPH $\times 100$

myosin light chain (MLC) phosphorylation (Data not shown) that involves in serotonin release [14, 69-72] in collagen- and ADP-activated platelets. These results are allowed to consider that WIB-801CE seems to attenuate ex vivo serotonin release by inhibiting the phosphorylation of $\mathrm{p}^{38 \text { MAPK }}$ and ERK2 rather than MLC in collagen- and ADP-activated platelets. This is similar to the reports that some phytochemicals (i.e. caffeic acid phenethyl ester, ginsenoside Rp1) inhibit collagen- and ADP-induced ATP release by phosphorylating $\mathrm{p}^{38}$ MAPK and ERK2 [39, 73].

In recent, we found that CE-WIB801C, n-butanol extracts from Cordyceps militalis, and cordycepin purified from CE-WIB801C has in vitro antiplatelet effect by inhibiting fibrinogen binding to glycoprotein IIb/IIIa via stimulation of cAMP-dependent phosphorylation of vasodilatorstimulated phosphoprotein $\left(\operatorname{Ser}^{157}\right)$, and inhibition of phosphatidylinositol-3 kinase/Akt phosphorylation [74]. Antiplatelet effect of CE-WIB801C was involved in inhibition of collagen-induced serotonin release. Accordingly, we confirmed that the extracts from Cordyceps militaris have antiplatelet effect in vitro and in vivo.

The formation of fibrin clot by intrinsic and extrinsic blood coagulation factors together with platelet aggregation at injured blood vessels is another cause of thrombogenesis. WIB-801CE did not significantly prolong PT and APTT as compared with that by normal ex vivo. This reflects that WIB-801CE has no anticoagulant characteristics. WIB-801CE, however, weakly prolonged average PT as compared with that by normal. The prolongation of PT is associated with the reduction of coagulation factor VII production by inhibition of NADPH-vitamin $\mathrm{K}$ reductase [75]. The dose $(1 \mathrm{mg} / \mathrm{kg}-\mathrm{BW})$ of warfarin, an inhibitor of $\mathrm{NADPH}$-vitamin $\mathrm{K}$ reductase, that unlimitedly prologned PT is corresponded to high dose (60 mg/day) in case of giving to human $(60 \mathrm{~kg})$, which is more 12 fold than

Table 5 Effects of cordycepin administration in ADP-induced rat platelet aggregation

\begin{tabular}{|c|c|c|}
\hline & $\begin{array}{l}\text { Light transmission } \\
\text { (\%) }\end{array}$ & $\begin{array}{l}\text { Inhibition } \\
(\%)\end{array}$ \\
\hline Control + ADP (10 $\mu \mathrm{M})$ & $75.7 \pm 0.6$ & - \\
\hline Cordycepin $(5 \mathrm{mg} / \mathrm{kg}-\mathrm{BW})+\mathrm{ADP}(10 \mu \mathrm{M})$ & $51.7 \pm 0.6^{* *}$ & 31.7 \\
\hline Cordycepin (10 mg/kg-BW) + ADP $(10 \mu \mathrm{M})$ & $47.3 \pm 2.5^{* *}$ & 37.4 \\
\hline
\end{tabular}

The data are given as the mean \pm standard deviation $(n=3) .{ }^{* * *} p<0.001$ compared with control. Inhibition $(\%)=[($ cordycepin + ADP $)-$ control $] /$ control $\times 100(\%)$ international normalized dose (5 mg/day) of warfarin [76]. In this study, because it is unknown whether the weak extension of average PT by WIB-801CE is clinically safety or risk, it is necessary to investigate PT using international normalized dose ( $5 \mathrm{mg} /$ day) of warfarin, then the safety of WIB-801CE in the weak extension of PT should be evaluated in the future.

In addition, WIB-801CE without significantly affecting the prolongation of blood coagulation time may not influence on inhibition of fibrin production. If so, because the fibrin is retracted by the interaction with platelet aggregation [77], anybody may apprehend that the thrombus could be generated by WIB-801CE in vivo. But it is considered that its fear can be excluded because WIB-801CE inhibited both thrombogenic $\mathrm{TXA}_{2}$ production and serotonin release ex vivo, and thrombin-induced fibrin clot retraction in vitro. These results mean that WIB-801CE can strongly inhibit the fibrin clot retraction by down-regulating platelet activation without significantly affecting the blood coagulation. This is also evidenced as the effect that WIB-801CE inhibited collagen plus epinephrine-induced acute pulmonary thromboembolism in vivo, which is a marker of platelet aggregation-generated thrombogenesis. At the present study, however, it is unknown whether cordycepin in WIB801CE contributed to the inhibition of acute pulmonary thromboembolism. These should be studied in the future.

As well as anticoagulants, antiplatelet drugs (i.e. aspirin, clopidogrel) also cause bleeding, and surprisingly may generate blood loss [21]. It is known that $20-40 \mathrm{mg}$ /day of aspirin is clinically used in human to protect thrombotic disease [78]. The dose (100 mg/kg-BW) of aspirin, a positive control, seriously prolonged tail bleeding time of mice as compared with that by control. This aspirin dose (100 mg/kg-BW) is corresponded to high dose $(6,000 \mathrm{mg} /$ day) in case of giving to human (60 kg), which is more $300-150$ fold than clinical dose (20-40 $\mathrm{mg} /$ day) of aspirin and impossible to compare with WIB-801CE in tail bleeding time of mice. At the present study, because it is unknown whether the significant extension of tail bleeding time by WIB-801CE is clinically safety or risk, it is necessary to investigate tail bleeding time using the clinical dose (20-40 mg/day) of aspirin as positive control, then the safety of WIB-801CE-prolonged tail bleeding time should be evaluated in the future.

Leukocyte-produced ROS oxidizes low density lipoprotein (LDL) in blood, then oxidized LDL (ox-LDL) is incorporated into macrophage to generate foam cell 
which damages vascular wall by inducing inflammation. Because platelet aggregation is caused at injured place of vascular wall, the inflammation by leukocyte-produced ROS and NO is the cause of thrombus formation. This means that the counteraction of agonists-induced platelet aggregation and leukocyte-induced inflammation might be contributed to the inhibition of thrombosis. WIB801CE had ex vivo inhibitory effects on the release of serotonin that stimulates the uptake of ox-LDL into macrophage [79]. In addition, WIB-801CE inhibited NO production and elevated scavenging activity of free radical in DPPH in vitro. Therefore, it is anticipated that WIB801CE would not activate inflammatory leukocytes in vivo as evidenced that WIB-801CE dose not affect ex vivo NO production. These results suggest that WIB-801CE might have antithrombotic effects by inhibiting inflammation via antioxidative action.

Because we could not identify cordycepin or its metabolites in PRP from WIB-801CE (200, $400 \mathrm{mg} / \mathrm{kg}-\mathrm{BW})$ rats, in the present study, we could not explain whether cordycepin in WIB-801CE was absorbed through intestine and subsequently involved in inhibition of platelet aggregation. This study should be performed in the future. Considering antiplatelet effects observed by blood collection of $2 \mathrm{~h}$ after final administration of WIB-801CE and 14 days after administration of cordycepin, although cordycepin is metabolized to an inactive 3'-deoxyhypoxanthinosine by adenosine deaminase in rat blood [80-82], it could be thought that unknown substances in WIB-801CE or cordycepin-derived unknown substance might involve in inhibition of platelet aggregation in an acute or chronic manner.

WIB-801CE (200, $400 \mathrm{mg} / \mathrm{kg}$-BW)-dose independently exerted its inhibitory effects on platelet aggregation, $\mathrm{TXA}_{2}$ production, AA release, TXAS activity, serotonin release, $\mathrm{p}^{38}$ MAPK phosphorylation and ERK2 phosphorylation in ADP-activated platelets. Considering the inhibition of ADP-induced platelet aggregation is a potential target to develop antithrombotic agent having antiplatelet characteristics [36. 37], it is thought that high dose of WIB-801CE (400 mg/kg-BW) might exert undesirable effect on platelets in vivo.

\section{Conclusion}

Cordycepin-enriched WIB-801CE from Cordyceps militaris vanished ex vivo thrombogenic molecules $\left(\mathrm{TXA}_{2}\right.$, serotonin), and their associated signaling molecules (AA, TXAS, $\mathrm{p}^{38 \text { MAPK }}$, ERK2) in platelet aggregation. Furthermore, WIB$801 C E$ inhibited in vivo acute pulmonary thromboembolism, an index of thrombotic formation, without having cytotoxicity and risk of serious bleeding, but with antioxidant and antiinflammatory activity. Therefore, we suggest that WIB-801CE may be a beneficial and effective substance to treat or protect thrombosis, atherosclerosis, and myocardial infarction via inhibition of platelet activation in vivo.

\section{Abbreviations}

AA: Arachidonic acid; AC: Ascorbic acid; ADP: Adenosine diphosphate; AG: Amino guanidine; ANOVA: Analysis of variance; APTT: Activated partial thromboplastin time; ATCC: American type culture collection; BW: Body weight; COX-1: Cyclooxygenase-1; CPLA 2 : Cytosolic phospholipase $\mathrm{A}_{2}$; DG: Diacylglycerol; DPPH: 2,2-diphenyl-1-picrylhydrazyl; ECL: Enhanced chemiluminescence solution; EIA: Enzyme immunoassay; ELISA: Enzymelinked immunosorbent assay; ERK: Extracellular signal-regulated kinase; HPLC: High performance liquid chromatography; HRP: Horseradish peroxidase conjugate; ICR: Institute of Cancer Research; IgG: Immunoglobulin G; iNOS: Inducible nitric oxide synthase; KRBC: Korean Red Cross Blood Center; LDH: Lactate dehydrogenase; LDL: Low density lipoprotein; LPS: Lipopolysaccharide; MAPK: Mitogen-activated protein kinase; MLC: Myosin light chain; MLCK: Myosin light chain kinase; NO: Nitric oxide; ox-LDL: Oxidized low density lipoprotein; $\mathrm{PGH}_{2}$ : Prostaglandin $\mathrm{H}_{2} ; \mathrm{PLC}$ ${ }_{\beta 3}$ : Phospholipase $C_{\beta 3} ;$ PLC ${ }_{\gamma 2}$ : Phospholipase $C_{\gamma 2} ;$ PPP: Platelet-poor plasma; PRP: Platelet-rich plasma; PT: Prothrombin time; PVDF: Polyvinylidene difluoride; ROS: Reactive oxygen species; SDS-PAGE: Sodium dodecyl sulfate-polyacrylamide gel electrophoresis; TXA TXAS: TXA $A_{2}$ synthase; TXB $_{2}$ : Thromboxane $\mathrm{B}_{2}$; WIB-801CE: (Compound from 2008 First Project of Bioteam, Whanin Pharm. Co., Ltd., Suwon, Korea), an ethanol extract from Cordyceps militaris-hypha

\section{Acknowledgements}

Authors of Inje University are thankful to Whanin Pharm. Co., Ltd., for the supply of WIB-801CE and PRP from animal administration of WIB-801CE, and cordycepin analysis and in vivo experiment.

\section{Funding}

This study was supported the Basic Science Research Program via the National Research Foundation of Korea (NRF) funded by the Ministry of Education, Science and Technology, Korea (NRF-2011-0012143 to Hwa-Jin Park) and in part by a grant from Whanin Pharm. Co., Ltd. (Suwon, Korea).

\section{Availability of data and materials}

The contents of this manuscript was argued and are useful on requirement from the corresponding author.

\section{Authors' contributions}

Conception and design of the experiment: HJP JLK. Performance of the experiment: HWK JHS DHL WJO GSN MJK HKK JHN JYL. Analysis and arrangement of the data: HWK JHS DHL WJO GSN MJK HKK JHN JYL HHK. Contribution of reagents, materials, and tool: HWK JHS DHL. Interpretation of the data: HWK JHS DHL WJO HJP. Writing of initial paper drafts: HJP. Contribution of manuscript preparation: HWK JHS DHL HHK. All authors read and approved the final manuscript.

\section{Competing interests}

Inje University has performed the measurement of cytotoxicity, platelet aggregation, $\mathrm{TXA}_{2}$, activities of $\mathrm{CPLA}_{2}, \mathrm{PLC}_{\beta 3}$ and $\mathrm{PLC} \mathrm{C}_{\gamma 2}$, arachidonic acid release, serotonin release, COX-1 activity, TXAS activity, phosphorylation of $\mathrm{p}^{38 \mathrm{MAPK}}$ and ERKs, fibrin clot retraction, NO production of WIB-801CE (200, $400 \mathrm{mg} / \mathrm{kg}-\mathrm{BW}$ ), oxidation, ex vivo antiplatelet effect of cordycepin and supplemental experiments. These above experiments are supported by the Basic Science Research Program via the National Research Foundation of Korea (NRF) funded by the Ministry of Education, Science and Technology, Korea (NRF-2011-0012143 to Hwa-Jin Park). Whanin Pharmaceutical Company supplied in part fund and analyzed cordycepin contents in WIB-801CE, and performed animal administration and subsequently measured blood coagulation- and tail bleeding-time and evaluated acute pulmonary thromboembolism, and also assayed in vitro NO production. The authors of Whanin Pharmaceutical Company and Inje University declare that they have no potential competing interests.

\section{Consent for publication}

The authors agreed to publish the results of this study.

\section{Ethics approval and consent to participate}

The experiments of human platelets were followed the guidelines of The Korea National Institute for Bioethics Policy Public Institutional Review Board (Seoul, Korea/PIRB12-072-01). The animal experiments were performed as per the Ethics Committee of Whanin Pharmaceutical Corporation (Suwon, Korea/ 
15-NE-016 for rats, 15-NE-008 for mice). The experimental use of human PRP was approved by the Korean Red Cross Blood Center (Safety Supervisor Team-621-2015.02.26).

Received: 1 June 2016 Accepted: 16 November 2016 Published online: 07 December 2016

\section{References}

1. Cunningham KG, Hutchinson SA, Manson W, Spring FS. Cordycepin, a metabolic product from cultures of Cordyceps militaris (Linn.) Link. Part I. Isolation and characterization. J Chem Soc. 1951:2:2299-300.

2. Ng TB, Wang HX. Pharmacological actions of Cordyceps, a prized folk medicine. J Pharm Pharmacol. 2005;57:1509-19.

3. Cho HJ, Cho JY, Rhee MH, Park HJ. Cordycepin (3'-deoxyadenosine) inhibits human platelet aggregation in a cyclic AMP- and cyclic GMP-dependent manner. Eur J Pharmacol. 2007;558:43-51.

4. Berridge MJ, Irvine RF. Inositol trisphosphate, a novel second messenger in cellular signal transduction. Nature. 1984;312:315-21.

5. Jennings LK. Role of platelets in atherothrombosis. Am J Cardiol. 2009;103: $4 \mathrm{~A}-10 \mathrm{~A}$.

6. Rosado JA, Sage SO. Phosphoinositides are required for store-mediated calcium entry in human platelets. J Biol Chem. 2000;275:9110-3.

7. Rosado JA, Sage SO. Coupling between inositol 1,4,5-trisphosphate receptors and human transient receptor potential channel 1 when intracellular Ca2+ stores are depleted. Biochem J. 2000;350:631-5.

8. Schwartz SM, Heinmark RL, Majesky MW. Developmental mechanisms underlying pathology of arteries. Physiol Rev. 1990;70:1177-209.

9. Lin LL, Wartmann M, Lin AY, Knopf JL, Seth A, Davis RJ. CPLA2 is phosphorylated and activated by MAP kinase. Cell. 1993;72:269-78.

10. Leslie CC. Regulation of the specific release of arachidonic acid by cytosolic phospholipase A2. Prostaglandins Leukot Essent Fatty Acids. 2004;70:373-6.

11. Samuelsson B, Goldyne M, Granström E, Hamberg M, Hammarström S, Malmsten C. Prostaglandins and thromboxanes. Annu Rev Biochem. 1978;47:997-1029.

12. Guidetti GF, Lova P, Bernardi B, Campus F, Baldanzi G, Graziani A, Balduini C, Torti M. The Gi-coupled P2Y12 receptor regulates diacylglycerol-mediated signaling in human platelets. J Biol Chem. 2008;283:28795-805.

13. Lewis GP, Watts IS. Prostaglandin endoperoxides, thromboxane A2 and adenosine diphosphate in collagen-induced aggregation of rabbit platelets. Br J Pharmacol. 1982;75:623-31.

14. Nishikawa M, Tanaka T, Hidaka H. Ca2 + -calmodulin-dependent phosphorylation and platelet secretion. Nature. 1980;287:863-5.

15. Malmsten C, Hamberg M, Svensson J, Samuelsson B. Physiological role of an endoperoxide in human platelets: hemostatic defect due to platelet cyclooxygenase deficiency. Proc Natl Acad Sci USA. 1975;72:1446-50.

16. Li Z, Delaney MK, O'Brien KA, Du X. Signaling during platelet adhesion and activation. Arterioscler Thromb Vasc Biol. 2010;30:2341-9.

17. Zhang L, Du JR, Wang J, Yu DK, Chen YS, He Y, Wang CY. Z-ligustilide extracted from Radix Angelica Sinensis decreased platelet aggregation induced by ADP ex vivo and arterio-venous shunt thrombosis in vivo in rats. Yakugaku Zasshi. 2009:129:855-9.

18. Cho HJ, Choi SA, Kim CG, Hong JH, Park HJ, Park HJ. Dietary spinach saponin-enriched lipophilic fraction inhibits platelet aggregation and blood coagulation. J Med Food. 2011;14:784-91.

19. Yu JY, Jin YR, Lee JJ, Chung JH, Noh JY, You SH, Kim KN, Im JH, Lee JH, Seo JM, et al. Antiplatelet and antithrombotic activities of Korean Red Ginseng. Arch Pharm Res. 2006;29:898-903.

20. Laemmli UK. Cleavage of structural proteins during the assembly of the head of bacteriophage T4. Nature. 1970;227:680-5.

21. Xiang YZ, Xia Y, Gao XM, Shang HC, Kang LY, Zhang BL. Platelet activation, and antiplatelet targets and agents: current and novel strategies. Drugs. 2008;68:1647-64.

22. Kim MS, Lee KA. Antithrombotic activity of methanolic extract of Umbilicaria esculenta. J Ethnopharmacol. 2006;105:342-5.

23. DiMinno G, Silver MJ. Mouse antithrombotic assay: a simple method for the evaluation of antithrombotic agents in vivo. Potentiation of antithrombotic activity by ethyl alcohol. J Pharmacol Exp Ther. 1983;225:57-60.

24. Fox JE, Taylor RG, Taffarel M, Boyles JK, Goll DE. Evidence that activation of platelet calpain is induced as a consequence of binding of adhesive ligand to the integrin, glycoprotein IIb-IIla. J Cell Biol. 1993;120:1501-7.

25. Cotelle N, Bernier JL, Catteau JP, Pommery J, Wallet JC, Gaydou EM. Antioxidant properties of hydroxy-flavones. Free Radic Biol Med. 1996;20:35-43.
26. Dore CM, das C Faustino Alves MG, Will LS, Costa TG, Sabry DA, de Souza Rêgo LA, Accardo CM, Rocha HA, Filgueira LG, Leite EL. A sulfated polysaccharide, fucans, isolated from brown algae Sargassum vulgare with anticoagulant, antithrombotic, antioxidant and anti-inflammatory effects. Carbohydr Polym. 2013;91:467-75.

27. Yoshikawa N, Nakamura K, Yamaguchi Y, Kagota S, Shinozuka K, Kunitomo M. Antitumour activity of cordycepin in mice. Clin Exp Pharmacol P. 2004;31:S51-3.

28. Huang LF, Liang YZ, Guo FQ, Zhou ZF, Cheng BM. Simultaneous separation and determination of active components in Cordyceps sinensis and Cordyceps militaris by LC/ESI-MS. J Pharm Biomed Anal. 2003;33:1155-62.

29. Yue GG, Lau CB, Fung KP, Leung PC, Ko WH. Effects of Cordyceps sinensis, Cordyceps militaris and their isolated compounds on ion transport in Calu-3 human airway epithelial cells. J Ethnopharmacol. 2008;117:92-101.

30. Marcus AJ, Zucker-Franklin D, Safier LB, Ullman HL. Studies on human platelet granules and membranes. J Clin Invest. 1996:45:14-28.

31. Goode DJ, Meltzer HY. Cytotoxic effects of imipramine on platelets. Biochem Pharmacol. 1974:23:2629-35.

32. Fujiwara Y, Banno H, Shinkai Y, Yamamoto C, Kaji T, Satoh M. Protective effect of pretreatment with cilostazol on cytotoxicity of cadmium and arsenite in cultured vascular endothelial cells. J Toxicol Sci. 2011;36:155-61.

33. Duguid JB. Thrombosis as a factor in the pathogenesis of coronary atherosclerosis. J Pathol Bacteriol. 1946;58:207-12.

34. Cahill MR, Newland AC. Platelet activation in coronary artery disease. Br J Biomed Sci. 1993;50:221-34.

35. Grau AJ, Ruf A, Vogt A, Lichy C, Buggle F, Patscheke H, Hacke W. Increased fraction of circulating activated platelets in acute and previous cerebrovascular ischemia. Thromb Haemost. 1998;80:298-301.

36. Bhatt DL, Topol EJ. Scientific and therapeutic advances in antiplatelet therapy. Nat Rev Drug Discov. 2003;2:15-28.

37. Jackson SP, Schoenwaelder SM. Antiplatelet therapy: in search of the 'magic bullet'. Nat Rev Drug Discov. 2003;2:775-89.

38. Adam F, Kauskot A, Rosa JP, Bryckaert M. Mitogen-activated protein kinases in hemostasis and thrombosis. J Thromb Haemost. 2008;6:2007-16.

39. Hsiao $\mathrm{G}$, Lee JJ, Lin $\mathrm{KH}$, Shen $\mathrm{CH}$, Fong $\mathrm{TH}$, Chou DS, Sheu JR. Characterization of a novel and potent collagen antagonist, caffeic acid phenethyl ester, in human platelets: in vitro and in vivo studies. Cardiovasc Res. 2007;75:782-92.

40. Kim SD, Lee IK, Lee WM, Cho JY, Park HJ, Oh JW, Park SC, Kim SK, Kwak YS, Yun $\mathrm{BS}$, et al. The mechanism of anti-platelet activity of davallialactone: involvement of intracellular calcium ions, extracellular signal-regulated kinase 2 and p38 mitogen-activated protein kinase. Eur J Pharmacol. 2008;584:361-7.

41. Flevaris $P$, Li Z, Zhang G, Zheng Y, Liu J, Du X. Two distinct roles of mitogenactivated protein kinases in platelets and a novel Rac1-MAPK-dependent integrin outside-in retractile signaling pathway. Blood. 2009:113:893-901.

42. Leslie CC, Gangelhoff TA, Gelb MH. Localization and function of cytosolic phospholipase A2 alpha at the Golgi. Biochimie. 2010;92:620-6.

43. Moscardó A, Vallés J, Latorre A, Madrid I, Santos MT. Reduction of platelet cytosolic phospholipase A2 activity by atorvastatin and simvastatin: biochemical regulatory mechanisms. Thromb Res. 2013:131:e154-9.

44. Börsch-Haubold AG, Pasquet S, Watson SP. Direct inhibition of cyclooxygenase-1 and -2 by the kinase inhibitors SB 203580 and PD 98059. J Biol Chem. 1998;273:28766-72.

45. Jackson EC, Ortar G, McNicol A. The effects of an inhibitor of diglyceride lipase on collagen-induced platelet activation. J Pharmacol Exp Ther. 2013; 347:582-8.

46. Bi Y, Guo XK, Zhao H, Gao L, Wang L, Tang J, Feng WH. Highly pathogenic porcine reproductive and respiratory syndrome virus induces prostaglandin E2 production through cyclooxygenase 1, which is dependent on the ERK1/ 2-p-C/EBP- $\beta$ pathway. J Virol. 2014;88:2810-20.

47. Colman RW. Overview of Hemostasis. In: Clowes AW, George JN, Goldhaber SZ, Marder VJ, editors. Hemostasis and thrombosis: Basic principles and clinical practice. 5th ed. Philadelphia: Lippincott; 2006. p. 3-16.

48. Colman RW. Are hemostasis and thrombosis two sides of the same coin? Exp Med. 2006:203:493-5.

49. Klafke JZ, Arnoldi da Silva M, Fortes Rossato M, Trevisan G, Banderó Walker Cl, Martins Leal CA, Olschowsky Borges D, Chitolina Schetinger MR, Noal Moresco $\mathrm{R}$, et al. Antiplatelet, antithrombotic, and fibrinolytic activities of campomanesia xanthocarpa. Evid-Based Compl Alt. 2012; DOl:10.1155/2012/954748

50. Zhou YJ, Xiang JZ, Yuan H, Liu H, Tang Q, Hao HZ, Yin Z, Wang J, Ming ZY. Neferine exerts its antithrombotic effect by inhibiting platelet aggregation and promoting dissociation of platelet aggregates. Thromb Res. 2013;132:202-10. 
51. Choi JH, Kim S, Kim SJ. Spirulan from blue-green algae inhibits fibrin and blood clots: its potent antithrombotic effects. J Biochem Mol Toxicol. 2015;29:240-8.

52. Phillips DR, Conley PB, Sinha U, Andre P. Therapeutic approaches in arterial thrombosis. J Thromb Haemost. 2005:3:1577-89.

53. Davì G, Patrono C. Platelet activation and atherothrombosis. N Engl J Med. 2007:357:2482-94

54. Abrantes DC, Brunini TM, Matsuura C, Mury W, Corrêa CR, Santos SF, Carmo MB O d, Mendes-Ribeiro AC. Diminished nitric oxide generation from neutrophils suppresses platelet activation in chronic renal failure. Mol Cell Biochem. 2015;401: 147-53.

55. Freedman JE. Oxidative stress and platelets. Arterioscler Thromb Vasc Biol. 2008:28:s11-6.

56. Higashi Y, Noma K, Yoshizumi M, Kihara Y. Endothelial function and oxidative stress in cardiovascular diseases. Circ J. 2009;73:411-8.

57. Gros A, Ollivier V, Ho-Tin-Noé B. Platelets in inflammation: regulation of leukocyte activities and vascular repair. Front Immunol. 2015; DOI: 10.3389/ fimmu.2014.00678

58. FitzGerald GA. Mechanisms of platelet activation: thromboxane $A 2$ as an amplifying signal for other agonists. Am J Cardiol. 1991;68:11B-5B.

59. Ruggeri ZM. Platelets in atherothrombosis. Nat Med. 2002;8:1227-34.

60. Lee DH, Kim YJ, Kim HH, Cho HJ, Ryu JH, Rhee MH, Park HJ. Inhibitory effects of epigallocatechin-3-gallate on microsomal cyclooxygenase-1 activity in platelets. Biomol Ther. 2013;21:54-9.

61. Lee DH, Kim HH, Cho HJ, Bae JS, Yu YB, Park HJ. Antiplatelet effects of caffeic acid due to Ca2+ mobilization inhibition via CAMP-dependent inositol-1, 4, 5trisphosphate receptor phosphorylation. J Atheroscler Thromb. 2014;21:23-37.

62. Park JB. 5-Caffeoylquinic acid and caffeic acid orally administered suppress P-selectin expression on mouse platelets. J Nutr Biochem. 2009;20:800-5.

63. Cho HJ, Kang HJ, Kim YJ, Lee DH, Kwon HW, Kim YY, Park HJ. Inhibition of platelet aggregation by chlorogenic acid via CAMP and cGMP-dependent manner. Blood Coagul Fibrin. 2012;23:629-35.

64. Park JB. Caffedymine from cocoa has COX inhibitory activity suppressing the expression of a platelet activation marker, P-selectin. J Agr Food Chem. 2007;55:2171-5

65. Jeng $J H, W u H L$, Lin BR, Lan WH, Chang HH, Ho YS, Lee PH, Wang YJ, Wang JS, Chen YJ, et al. Antiplatelet effect of sanguinarine is correlated to calcium mobilization, thromboxane and cAMP production. Atherosclerosis. 2007;191:250-8.

66. Mustard JF, Packham MA. Factors influencing platelet function: adhesion, release, and aggregation. Pharmacol Rev. 1970;22:97-187.

67. Holmsen H. Prostaglandin endoperoxide-thromboxane synthesis and dense granule secretion as positive feedback loops in the propagation of platelet responses during "the basic platelet reaction". Thromb Haemost. 1977:38:1030-41.

68. Borgdorff P, Tangelder GJ. Migraine: possible role of shear-induced platelet aggregation with serotonin release. Headache. 2012;52:1298-318.

69. Rosado JA, Sage SO. The actin cytoskeleton in store-mediated calcium entry. J Physiol. 2000;526:221-9.

70. Rosado JA, Sage SO. A role for the actin cytoskeleton in the initiation and maintenance of store-mediated calcium entry in human platelets. J Trends Cardiovasc Med. 2000;10:327-32.

71. Rosado JA, Sage SO. Role of the ERK pathway in the activation of storemediated calcium entry in human platelets. J Biol Chem. 2001;276:15659-65.

72. Kaibuchi K, Sano K, Hoshijima M, Takai Y, Nishizuka Y. Phosphatidylinositol turnover in platelet activation; calcium mobilization and protein phosphorylation. Cell Calcium. 1982;3:323-35.

73. Endale M, Lee WM, Kamruzzaman SM, Kim SD, Park JY, Park MH, Park TY, Park $\mathrm{HJ}$, Cho JY, Rhee MH. Ginsenoside-Rp1 inhibits platelet activation and thrombus formation via impaired glycoprotein VI signalling pathway, tyrosine phosphorylation and MAPK activation. Brit J Pharmacol. 2012;167:109-27.

74. Lee DH, Kim HH, Lim DH, Kim JL, Park HJ. Effect of cordycepin-enriched WIB801C from Cordyceps militaris suppressing fibrinogen binding to glycoprotein IIb/llla. Biomol Ther. 2015;23:60-70.

75. Harrison L, Johnston M, Massicotte MP, Crowther M, Moffat K, Hirsh J. Comparison of 5-mg and 10-mg loading doses in initiation of warfarin therapy. Ann Intern Med. 1997;126:133-6.

76. Jaffer A, Bragg L. Practical tips for warfarin dosing and monitoring. Clev Clin J Med. 2003;70:361-71.

77. de Witt SM, Verdoold R, Cosemans JM, Heemskerk JW. Insights into plateletbased control of coagulation. Thromb Res. 2014;133:S139-48.
78. FitzGerald GA, Oates JA, Hawiger J, Maas RL, Roberts 2nd L, Lawson JA, Brash AR. Endogenous biosynthesis of prostacyclin and thromboxane and platelet function during chronic administration of aspirin in man. J Clin Invest. 1983;71:676-88.

79. Aviram M, Fuhrman B, Maor I, Brook GJ. Serotonin increases macrophage uptake of oxidized low density lipoprotein. Eur J Clin Chem Clin Biochem. 1992;30:55-61.

80. Adamson RH, Zaharevitz DW, Johns DG. Enhancement of the biological activity of adenosine analogs by the adenosine deaminase inhibitor 2'deoxycoformycin. Pharmacology. 1977;15:84-9.

81. Tsai YJ, Lin LC, Tsai TH. Pharmacokinetics of adenosine and cordycepin, a bioactive constituent of Cordyceps sinensis in rat. J Agr Food Chem. 2010;58:4638-43.

82. Rodman LE, Farnell DR, Coyne JM, Allan PW, Hill DL, Duncan KL, Page JG. Toxicity of cordycepin in combination with the adenosine deaminase inhibitor 2'-deoxycoformycin in beagle dogs. Toxicol Appl Pharm. 1997;147:39-45.

\section{Submit your next manuscript to BioMed Central and we will help you at every step:}

- We accept pre-submission inquiries

- Our selector tool helps you to find the most relevant journal

- We provide round the clock customer support

- Convenient online submission

- Thorough peer review

- Inclusion in PubMed and all major indexing services

- Maximum visibility for your research

Submit your manuscript at www.biomedcentral.com/submit
Ciomed Central 